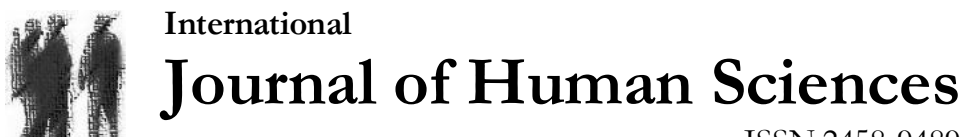 \\ ISSN:2458-9489
}

Volume 18 Issue 3 Year: 2021

\section{Showing meaning and providing expression order of Turkish language}

\section{Türkçenin anlam gösterme ve anlatım gerçekleştirme düzeni}

\section{Mehmet Gedizli ${ }^{1}$}

\section{Özet}

Bu çalışmada Türkçenin anlam gösterme ve anlatım gerçekleştirme yöntemleri ortaya konulmuştur. Konu, dilin "anlaşmayı sağlama işlevi" bağlamında ele alınmıştır. Kaynaklarda doğrudan bu konuyla ilgili herhangi bir çalışmayla karşılaşılmamıştır. Bundan dolay1 çalışmanın yenilikçi bir yönü vardır.

Dil tanımlarında "dilin iletişim aracı" olduğuna vurgu yapılır. Bu çalışma, dili "anlaşma aracı"” olarak değerlendirerek Türkçenin anlam gösteren ve anlatım gerçekleştiren birimlerini tanzim ve tasnif etmektedir. Çalışma, temel kavramlar, anlam gösterme ve anlatım gerçekleştirme düzeni şeklinde üç bölümden oluşmaktadır. Temel kavramlarda dilin anlam gösterme ve anlatım anlatım gerçekleştirme özelliklerini doğrudan etkileyen kavramlar ilişkilendirilmiştir. Anlam gösterme düzeninde ses, kelime ve öbek unsurlarının anlam gösterimindeki işlevleri Türkçedeki örneklerle tartışlmıştır. Anlatım gerçekleştirme düzeninde de ifade, cümle ve metnin Türkçede anlatımın gerçekleştirilmesine katkıları ele alınmıştur.

Çalışmanın genelinde, Türkçenin bağlam kurma ve dönüşüm gerçekleştirme özelliklerine vurgu yapılarak ilgililerin dikkatine sunulmuştur. Türkçe dil bilgisi kitaplarının kuralcı yaklaşımına karşı bu çalışma, dil birimlerinin dilin temel işlevi olan "anlaşmayı sağlama" ilkesine göre düzenlenmesi gerektiğini belirtmiştir. Türkçenin anlam ve anlatum düzeninin "söz" temelinde

1 Assoc. Prof. Dr., Manisa Celâl Bayar University, Faculty of Education, Turkish and Social Sciences Education Department, mgedizli@gmail.com, (iD) Orcid ID: 0000-0002-2562-9492 
Gedizli, M. (2021). Türkçenin anlam gösterme ve anlatım gerçekleştirme düzeni. Journal of Human Sciences, 18(3), 400-430. doi:10.14687/jhs.v18i3.6195

language units be arranged according to the principle of "making agreement", which is the basic function of language. Asserting that the meaning and expression order of Turkish is grounded on "word", this study can be evaluated as a theoretical approach.

Keywords: Turkish, Word, Meaning, Expression, Agreement.

(Extended English summary is at the end of this document) işlediğinin ileri sürüldüğü bu çalışma, kuramsal bir yaklaşım olarak değerlendirilebilir.

Anahtar Kelimeler: Türkçe, Söz, Anlam, Anlatım, Anlaşma.

\section{Giriş}

Dil insanlar arasında "anlaşma sağlayan" doğal bir araçtır. "anlaşma” bir yanıyla "anlam" diğer yanıyla da "anlatım"dan oluşur. Anlatım, "anlam" ve "anlatma" işinin birlikte yapıldığı bir etkinliktir. Genel olarak dilin gerçekleştirmiş olduğu "anlaşma”nın dildeki görünümlerinin belirlenmesi, dilin bilgisini doğru öğrenmeye yardımcı olur. Bundan dolayı dili oluşturan unsurları ve bu unsurların üstlenmiş oldukları görevlerin tespit edilmesi, dil ile ilgili yapılacak çalışmalarda yol gösterici olacaktır.

Türkçe dil bilgisi kitapları, dil birimlerini ses ve ses birliklerinin oluşturdukları yapılara göre değerlendirmektedir. Ses bilgisi başlı̆̆ı altında seslerin özellikleri, seslerin sınıflandırılması ve ses değişimleri, dilin "anlaşma sağlama" işlevinden bağımsız olarak ele alınmaktadır. Seslerin oluşturdukları birlikler de şekil bilgisi başlğ̆ altında "kelime, kök, ek, türetim, çekim ve edat" olarak incelemektedir. Cümle bilgisi ya da söz dizimi başlı̆̆ altında da seslerin oluşturdukları kelimelerin cümledeki görevlerine göre kelime grupları ve cümlenin ögeleri olarak birimleştirilmektedir. Dilin yapısını oluşturan ses, genel olarak dil bilgisi kaynaklarında "tek başına anlamsız" en küçük dil birimi olarak belirtilmektedir, ancak bu "en küçük anlamsız dil birimi”, varlık sebebi "anlaşma sağlama" aracı olan dili oluşturmaktadır. Daha açık bir ifadeyle anlamsız temel birimler, anlaşma (anlam gösteren ve anlatım gerçekleştiren) sağlayan bir düzen oluşturmaktadırlar. Dil bilgisinin bu şekilde bir çelişkiyle kurgulanması tartışmaya açıktır.

Dilin temel birimi olan "ses", gerçekten "anlamsız" mıdır? Dil, anlamı olmayan bir unsura görev verebilir mi? Var oluşunu ses ile inşa eden/kuran dil, seslerine anlam atfetmeden kendi ses tercihlerini neye göre belirlemektedir? Dilin kendi ses seçimi yoksa, başka dillerdeki kelimeleri kadrosuna dahil ederken neden kendi ses sistemi lehine ses değişimine gitmektedir? Ses ile anlam arasında nasıl bir ilişki vardır ya da bir ilişki var mıdır? Genel dil bilimi ve felsefenin kavram veya kavramlaştırma dediği, Türkçenin de ilk yazılı eserlerinden bu yana kullandığı "söz" kelimesi ve ona bağlı gelişen söz varllğııın görünümü ile Türkçede de yaygın olarak kullanılan "kelime" kelimesinin "ke-le-me: konuş-" anlamından türemiş olduğu bilgileri, Türkçe dil bilgisinde belirtilen "sesin anlamsızlığı" iddiasına itirazın gerekçesi olabilir mi?

Ferdinand de Saussure Genel Dilbilim Dersleri adlı eserinde dilin göstergeler sistemi olduğunu belirtir ve göstergenin bir gösteren bir de gösterilen özelliğinden bahseder. Konunun daha doğru anlaşılması için "kağıt" metaforunu kullanarak "gösteren ile gösterilen" ilişkisini kağıdın iki yüzü olarak ifade eder ve bunların kesin bir ayrımının imkansızlı̆ına vurgu yapar. Dil biliminin getirmiş olduğu bu yaklaşım, dili diğer bilimlerden ayırarak tek başına incelenebilir bir yapı, bir sistem olarak değerlendirir. Bir olgu olarak kabul ettiği dilin oluşumunda insanın doğuştan sahip olduğu "dil yetisi"ni önemli bir yere konumlandıran Saussure, ses organlarının varlığını da dil yetisi olgusuna dayandırır. Dil bilimi kuramı, dili birimlerine ayrıştırıp incelebilir bir yap1 olarak konumlandırmış ve dil bilgisinin kuralcı ya da buyurgan tavrına da bir itiraz geliştirmiştir. 
Klasik dil bilgisi dili -bilinen en eski kaynaklara göre- kelimeler üzerinden incelemiştir. İsimler, filller ve edatlar olarak tasnif dilen dil birimleri, dil içindeki görevlerine göre ayrıca kendi içinde de sınıflandırılmıştır. Saussure'ün genel dil bilimi kuramıyla ortaya koyduğu ilkeler, dillerin incelenmesinde çok fazla ve çok farklı yaklaşımların geliştirilebilmesine imkan tanıması, dilleri belli ölçütlere sığdırmaya çalışmak yerine dilleri kendi var oluş biçimlerine göre inceleyip değerlendirme firsatı sunmuştur. Türkçenin dil bilgisi kitapları klasik dil bilgisinin yöntemlerine göre biçimlemektedir. Özellikle ses bilgisi ile ilgili konularda Türkçenin ses özellikleri hem tarihi hem de çağdaş dönemlere göre kapsamlı araştırmalarla ortaya konulmuştur. Şekil bilgisi, Türkçenin karakteristik özellikleri ile ilgili belirleyici olmuş ve bu yöndeki çalışmalar, genellikle aynı yöntem ve yaklaşımlarla sürdürülmektedir. Bu kapsamdaki çalışmalarda klasik dil bilgisinin buyurgan tavrı öne çıkmış ve kurallara uygunluk denetimleri esas alınmıştır. Türkçe dil bilgisinin alt alanı olan şekil bilgisi, Türkçenin bilgi sisteminin en kapsamlı gözlemlendiği kısmı oluşturur. Kelime ve eklerin merkezde olduğu şekil bilgisi, dil bilgisi sorunlarının da en fazla gözlemlendiği ve tartışıldığı alandır. Buna rağmen Türkçenin dil bilgisi sorunlarının çözümü için dil bilgisi ile ilgili yeterince yöntem ve yaklaşım geliştirebildiği söylenemez. Hatta bu alan kapsamında üretilen çözümler, yeni dil bilgisi sorunlarının ortaya çıkışına da sebep olmaktadır.

Türkçe dil bilgisinin diğer alt alanı ise cümle bilgisi ya da söz dizimidir. Cümlenin ögelerinin incelendiği bu bölümde de bilgi sorunları çok yönlü olarak tartışılmaktadır. Dil bilgisinin temel birimlerinden biri olan "cümle" terimi "sözdizimi/söz dizimi”" şeklinde değiştirilmesine rağmen cümle unsurları ile ilgili ihtilaflar, dil bilgisel ittifaklara evrilememiştir. Son yıllarda dil bilgisi kitaplarında "anlam bilgisi ya da anlam bilimi" konularına da yer verilmeye başlanmıştır. Anlam bilimi ile ilgili yaklaşımlar, dilin diğer bilgi alanlarıyla ilişkilendirilmemektedir. Dilin anlam ile ilgili özelliklerinin anlatıldığı bu bölümdeki bilgilerin ses bilgisi ile ilgili konularda olduğu gibi anlam ve anlatımın ses, şekil, cümle ve metin ile ilgisine değinilmemesi, Türkçenin dil bilgisinin bir bütün olarak değerlendirilmesini engellemektedir. Dil bilgisi, dilin bilgisini bir bütün olarak düzenlemek zorundadır. Bütünlüğün oluşturulamadığı dil bilgisi kitapları, dilin anlaşılırllğını yeterince sağlayamadığ1 gibi eğitim öğretim süreçlerini de olumsuz yönde etkilemektedir.

Anlaşma, karşı1ıklı uzlaşmayla gerçekleşir. Bir şey hakkında aynı kabulde olmak da anlaşmayı sağlar. Dili bir araç olarak kullanan anlamın dildeki konumuna göre kapsamı, dilden çok düşünceyle belirlenebilir. Dil bilgisi ve dil biliminin dilin temel birimi olan ses ile incelemeye başladığı dilin "anlam" ve "anlatım”" açıklamada bir sınırlılığının olduğu düşünülebilir. Çünkü anlamın ses ile doğrudan veya dolaylı ilgi ve ilişkisi, seslerin üretim ve işletimlerindeki bilgilerle kurulamaz. İnsan zihninin varlık ve olay karşısında göstermiş olduğu tepki, anlam hakkında yapılabilecek ilk işaretlemedir. Zihnin varlık ve olay karşısındaki tepki de farklıdır. Zihnin varlık algısı ile olay algısına verdiği tepkiler, hem zihnin algılayış biçimine hem de varlık ve olayın özelliğine göre değişir. Zihnin varlık alg1sı, koku, renk, ses, biçim ve diğer niteliklere göre belirlenir. Zihnin tepki göstermesine sebep olan uyarıcının sabit ve hareket olması, onların algılanış biçimlerini zaman, mekan ve yönelişine göre etkiler. Zihnin durmaksızın işler vaziyette olması, sabit varlıkları algılayış biçimine göre işaretlerken, kendisi gibi hareket halindeki olay/eylem varlıkları da kendi hareket haline göre konumlandırıp işaretlemektedir. İşaretler de yine algılamaya yardım eden organlar aracılığıyla ilgi ve ilişki biçimine göre belirlenmiş olduğu varsayılabilir, ancak anlamdan ziyade anlatıma araçlık ve aracılık eden dil ve kendi türünden varlıklarla (anlam) ilişkisi, anlamın görünümü hakkında daha fazla açıklayıcı olabilir. Zihnin olayları/hareketleri/eylemleri varlıklaştırabilmesi için sabit varlık şekline dönüştürmesi gerekmektedir. Zihin kendi dişındaki olayları, "olgu" şseklinde sabitlerken kendisi de hareket varlık olmasına kendisini sabitleyememektedir. Bir akış halinde var olan zihnin kendisini sabitlemesi, teorik olarak mümkün görünmediği gibi pratik olarak da zihnin görev ve sorumluluğunda olan bir faaliyet değildir. Zihnin algıladığ1 varlık ve olguları kendisine göre "var etmesi/varlıklaştırması" anlam gösterimi ya da anlamlandırma olarak adlandırılabilir. İnsan zihninin göstermiş olduğu çerçeveli tepkilerin oluşturduğu varlıkların (anlam) aralarında kurdukları ilgi ve ilişkilerin kendi niteliklerine göre düzenlenmesi ise kavramdır. 
Kavram, zihnin varlık ilişkileriyle yeni varlıklar var etmesi olarak değerlendirilebilir. Yaratıcılık olarak adlandırılan bu olgu, aslında kavramlaştırmadır. Yaratıcılık, olmayanlardan olmayanları var etmek ise, kavramlaştırma olanlardan olmayanları var edebilmektir. Kavramlaştırma ve yaratıcılığın doğası, ilgi ve ilişki kurgusuna dayandığından dolayı benzerlik gösterir, ancak olmayandan olmayanı var etme, insanlık tarihinin şu ana kadar kaydedebildiği bir tecrübeye sahip değildir. Zihnin akış şeklindeki işleyişini işlevlendirebilmesi de kavramlaştırabilme yeterliliğinin göstergesidir. Zihnin kendi akışını durdurup yeniden başlatması, akışının yönünü değiştirmesi vb. müdahale imkanı tanımadığı için olanla olmayanları var etme yeterliliğiyle sınırlandırmaktadır.

Anlamın kavranılabilmesi için zihinden (soyut) dünyaya (somut) inmesi gerekmektedir. Kavramın dünyaya inmesi/gelmesi/geçmesi/dönüşmesi, içinde bulunduğu salt soyutluktan dünya koşullarında kendisi olarak kalabilebileceği en nitelikli vasfi kazanma zorunluluğu vardır. Kavramın zihinden zihine geçişinde kullanabileceği araçlar sınırlıdır. Beş duyu organı dışında kullanılabilecek başka geçiş ya da taşınma aracı bulunmadığı için bunlardan kendisine en uygun olanı seçmektedir. Kavramların gösteriminde kullanılan en yaygın araçlardan biri resimdir. Anlaşabilmek için her kavram için resim çizmek, insan davranışları bakımından pek de ekonomik değildir. Bunun yerine kavramın ses yoluyla dünyalılaşması ve çok az bir zaman aralığında da kulak duyu organıyla alıcı zihine ulaşması hem doğal hem de işlevseldir. Kavramın dildeki adı “söz”dür. Söz, kavramın dildeki gösterimidir, ancak sözün kavramla ilişkisi, kavramın diğer ifade/gösterim araçlarıyla olan ilişkisinden farklı bir bağlama sahiptir. Söz, kavramı kendi dünyasına taşıyıp dönüştürerek söylenebilirliğini sağlayacaktır. Sözün bir yanı kavramlaştırma ile diğer yanı da dilleştirme (dil oluşumu) ile ilgilidir.

Söz, dil ile kavram arasında dilden yana işleyen ve gelişen bir varlıktır. Söze bu yükümlülüğü ses yüklemektedir. Ses ve söz arasındaki ilgi ve ilişki, anlam ile kavram, kavram ile söz arasındaki ilişkiyle paralellik gösterir. Sözün sese ya da ses evrenine dönüşümü, dilsel nitelik kazanmasını sağlar. Ses, sözü dünyalılaştırır. Ses dünyanın genelgeçer varlıklarından biridir ve uyarıcı etkisi oldukça yaygin ve işlevseldir. Sözün ses ile işaretlenmesi, sesi özel bir varllğa dönüştürür. Sesin söze özel bir düzgü oluşturması, insana ait bir davranıştır. İnsan sesinin söz için var olması, insanın kavramlaştırabilme yeterliliğiyle ilişkilendirilebilir. Ferdinand de Saussure'ün “dil yetisi” olarak bahsettiği bu yeterliliğin kaynağı, insanın dil davranışının temellerini oluşturur.

Ferdinand de Saussure'ün bahsettiği dil yetisi, konuşma organları olarak adlandırılan ses üretim organlarının ses üretimindeki yetkinliğine işaret eder. Dilin sesleri, genel olarak dünyadaki seslerden farklıdır. Ağız ve kulak arasında bir yol oluşturan dil sesleri, bir taraftan doğal bir insan davranışı diğer taraftan da seslerden inşa edilmiş bir söz evreni kurar. Dünyadaki seslerle ile dil sesleri arasındaki ayrışma, dil yetisinin kaynağını doğrudan gözlemleme imkanı sunmaktadır.

Ses kısaca, en az iki varlık arasındaki etkileşimin kulakta karşılık bulması olarak açıklanabilir. Ses için zorunlu olan üç temel unsur vardır; iki varlık, iki varlığın birbiriyle etkileşimi ve bu etkileşimin kulakta tepki oluşturması. Sesin oluşumu ve onayı, varlıkların niteliğine, etkileşimin özelliğine ve kulağın işitme yeterliliğine göre farklılık gösterebilir, ancak genel olarak ses, bu şekilde açıklanabilir. İnsanın çıkardığı farklı sesler vardır; horlama, inleme, kahkaha, sinirlenme, haykırma vs. $\mathrm{Bu}$ sesler de genel sesteki zorunlu koşulları yerine getirerek oluşmaktadır. İnsanın ses organlarının kavramları işaretlemek için ürettiği/çıkardığı sesler, sadece bu amaç için kullanılan dil sesleridir.

Kavramların işaretlenmesi için üretilen seslerin tamamı, nefesin vücuttan dişarıya çıkarılışı/verilişi sırasında oluşmaktadır. Genel sesteki zorunlu koşullar, dil seslerinin oluşumlarında da geçerlidir. İşaretleme seslerinin temel özelliği, tek bir amaç için üretilmiş olmalarıdır. Dil seslerinin her biri anlam/kavramda olduğu gibi belli bir niteliğe sahiptir. Sesi üreten kişinin fizyolojik özelliklerinin sese yansıması, sesi amacından uzaklaştıramaz. Kadın, erkek ve çocuk sesleri farklı özelliklere sahiptir. Aynı dili konuşan bu insanların ses farklılıkları dillerini ayrıştıramaz. Sesin işaretleyici işlevi korunur ve ses dilin işlevini gerçekleştirmesini sağlar. Diğer taraftan dil sesleri, kavram/söz işaretleme görevini yerine getirirken birim olarak kendini de kavramlaştırır. Her dilin /v/'si kendi söz anlayışına göredir. Türkçede /v/ sesi, diş-dudak sesi iken Arapçada sadece dudak 
sesi, İngilizcede ise Türkçedeki /o,u/ arası bir ses gibidir. Bundan dolayı her dilin ses düzeni, dilin kavramlaştırma özelliğine göre oluşmaktadır. Sesin kavramlaşması ona söz değeri kazandırır.

Sesler ilgi ve ilişkisel özelliğe sahiptir. / a/ tek başına kendinden başka bir şey ifade edemez. /a/'nın diğer seslerle ilişkileri ilgilerine göre oluşmaktadır. Bu noktada da dil sesleri ile anlamın/kavramın oluşumunu etkileyen tepkiler arasında benzer özellikler görülür. Ses, birim olarak kendini işaretlerken diğer taraftan sesler arası ilgi ve ilişkilerle oluşan birimlerle de sözü işaretler. Seslerin kavramları işaretlerken oluşturdukları ses öbekleşmelerindeki ilişki ve ilgi ile zihindeki çerçeveli tepkiler ve kavramlar arasındaki ilişki ve ilgi, sesin söze evrilmesini sağlamaktadır. Söz bir yanıyla ses diğer yanıyla da “değer”li bir dil birimidir. Sözün değeri, ne seslerden ne de kavramlardan kaynaklıdır. İradeden işarete, işaretten iradeye evrilişlerin dildeki tezahürü olan anlamın bağlamdaki işlevliliği, dilin ve sözün değeri hakkında fikir verebilir. Mesela /a/'nın tek başına kendinden başka bir şey olamaması gibi söz de ilgi ve ilişkiden yoksun kaldığı sürece kendisinden başka bir şey ifade etmez. Sözün değeri ilgi kurma ve ilişki gerçekleștirme işleviyle ortaya çıkar. Var olma özellikleri bakımından aslında dil sesi ile söz/kelime arasında birim ve biçim (öbekleşme) farklılığı dışında başka bir ayrımdan söz edilemez.

Ses ve söz arasındaki birimsel ve biçimsel ilişkinin bir sonraki halkası öbeklerdir. Sözün birim olarak işaretleyemediği ya da keyfiyete bağlı olarak dil kullanıcısının tercihine bağlı söz öbekleşmeleridir. En az iki söz birimin katılımıyla oluşan öbek, dilin temel işlevini gerçekleştirebilmesi için zorunlu birimdir. Öbeğin olmamas1, özellikle anlatımın gerçekleştirilmesini imkansız hale getirmektedir. Kavramlaştırma ile kavramlar arasında kurulan ilgi ve ilişki, dilde öbekleri gerekli kılmaktadır. O halde dilin anlaşmayı sağlama işlevini yerine getirebilmesi için ses, söz ve öbek birimleri zorunlu dil varlıkları olarak ortaya çıkmaktadır. Ortak temel özellikleri, ilgi ve ilişki kurup işaretleyerek anlaşmanın sağlanmasına aracılık etmektir. Teorik bir zemine yerleştirilmeye çalışılan dilin temel dil birimleri, dil bilgisinin kuruluşu için gereklidir. Türkçenin bilgi kuramı kendine özgüdür.

Genelde diller arası ilişkiler, dil dışı etkenlere bağlı olarak insan davranışlarının toplumsal niteliğine göre şekillenir. İnsanların toplu hareket etme zorunlulukları ve farklı dilleri konuşan insanların karışıp kaynaşması diller arası ilişkilerin doğal alanlarının oluşmasına sebep olur. Diğer yandan anlama ve dolayısıyla kavrama bağlı olarak amaçlı dil ilişkileri de diller arası "söz" geçişkenliğine doğrudan etki eder. İnanç ve din etkisine bağlı olarak Türkçeye geçen pek çok Arapça ve Farsça "söz" bu kapsamdadır. Dil ilişkilerine bağlı olarak da bir dil "söz varlığını" genişletebilir, ancak bazı diller "söz" geçişkenliği bakımından daha az "söz" alırken daha fazla "söz" verebilmektedir. Bu konuda dil dişı etkenler belirleyici olabildiği gibi dillerin karakteri de etkili olabilmektedir. Türkçe bu bağlamda oldukça esnek davranış sergileyen dillerden biridir. Dünyada pek çok dile diğer dillerden söz geçişi olmuştur. Bu noktada diller, söz hazinesine dahil olan ve ödünçleme de denilen sözleri ya olduğu gibi kabul etmişlerdir ya da kendi ses düzenine göre dönüştürmüşlerdir. Bunun yanında ödünçlenen sözleri işlev bakımından da ait olduğu dilden farklılaştırmışlardır. Türkçe, "söz"ü Arapçadan geçen "kelime” sözü ile işaretlemiştir. Kelime, Arapçada bir dil birimini işaret eder, Türkçede de dil bilgisi birimi olarak sözü işaretlemek için kullanılır. Arapçada "kelime" sadece anlamlı dil birimlerini işaretlerken Türkçede "söz" anlam gösteren ve anlatım gerçekleştiren birimlerden sadece birisidir. Yukarıda gösterildiği gibi söz, Türkçenin kurgusunun teorik zeminini oluşturmaktadır.

Bir varlık olarak dil, kendini gerçekleştirirken pek fazla sorun üretmez, bilakis sorun olma ihtimali olan durumları kendi işleyişine uygun olarak değiştirir, geliştirir ya da dönüştürür. Sorun genellikle dilin bilgisi ile ilgili düzenlemelerde ortaya çıkar. Yukarıda da belirtildiği gibi Türkçe bu yüzden dil bilgisi ile ilgili çok fazla sorunla uğraşmaktadır. Bu konuda izlenilmesi gereken bir takım yöntemler, sorunların doğrudan çözümünü sağlamasa bile çözümleri üretecek yöntemlerin geliştirilmesi için yeni yaklaşımlara yol açabilir. Diller, diğer dillerin bilgi sistemlerinden faydalanılabilir ki Türkçe dil bilgisi kitaplarında bu yolu fazlasıyla tercih etmektedir. İkinci bir yol olarak da dilin işleyişi ya da kendini var edişi/gerçekleştirmesi esas alınarak teorik bilgisi oluşturulabilir. Kuvvetli bir ihtimal olarak Türkçe dil bilgisi ile ilgili sorunların büyük bir kısmı da 
buradan kaynaklanmaktadır. Duruma açıklık getirmek bakımından "söllemek, anlatmak, konuşmak" sözleri genel olarak aynı işlevleri karşıllyormuş gibi görünmektedir, ancak bu sözlerin her birinin kendine ait alanları bulunmaktadır. "sarkı söylemek, șarkı anlatmak, șarkı konusmak"; "dert söllemek, dert anlatmak, dert konusmak" ve "ă̆rr söylemek, ağır anlatmak, ağır konusmak" örneklerinde görüldüğü gibi her söz, kendine ait bir ilgi ve ilişki evreni oluşturmaktadır. Her dilin grameri kendine göre biçimlenir. Varlıkla ilgi ve ilişkisini Türkçe yaşayan zihinlerin bilgi düzeni de Türkçe düzenlenmek durumundadir.

Türkçede “söz”̈̈n “anlam göstermek” ve "anlatım gerçekleştirmek” gibi işlevleri vardır. "Anlatım" anlaşmanın anlatıcısını, "mesaj/ileti" anlamını, "karşı anlatım/tepki”" de alıcısını/dinleyicisini oluşturur. Türkçede anlatımın temel birimi "cümle"dir. "anlaşma" cümle ile zapt altına alınır. Bundan dolayı cümle bir yanıyla "anlam gösterme" diğer yanıyla da "anlatım gerçekleştirme" işlevini üstlenir. "anlam gösterme" ile "anlatım gerçekleştirme" sözleri arasındaki ilgi ve ilişki, dizilişe göre değil söz düzgüsüne göre biçimlenir. Ses organlarının ses üretiminde sıraya göre davranması, dilde seslere diziliş özelliği kazandırsa da söz için aynı kural geçerli değildir. Anlatımda sözün düzgüsü esastır. Söz, amaca uygun olarak bir düzen oluşturur. Genel olarak Türkçe dil bilgisi söz düzgüsüne göre konumlandırılabilir. Bu yaklaşım mevcut dil bilgisi kaynaklarındaki düzenlemeden büyük oranda ayrışmaktadır. "söz” ün işaretleyiciliği ve işlevselliği arasındaki fark, dilin "anlaşma sağlama" işlevine göre değerlendirildiğinde Türkçenin doğal sistemine uygun bilgi düzenlemesi yapmak mümkündür.

\section{Amaç, Kapsam ve Yöntem}

Bu çalışmanın amac1, Türkçenin anlam gösterme ve anlatım gerçekleştirme özelliklerinin incelenmesidir. Türkçe ile ilgili araştırmalar oldukça geniş alanlara uzanmaktadır. Hem tarihi hem de güncel yönden yapılan çalışmalarda doğrudan doğruya üzerinde durulmadığı düşünülen Türkçenin "anlam gösterme ve anlatım gerçekleştirme" işlevi, bu çalışmanın ana konusunu oluşturur. Türkçenin dil bilgisi ile ilgili sorunlarının "yap1, işlev ve anlam” çerçevesinde incelendiği çalışmalara hem yöntem hem de yeni bakış açısı sunulmak istenmiştir. Dolayısıyla Türkçenin temel işlevi olan "anlaşmayı sağlama" ilkesine göre dil birimlerinin "anlam gösterme" ve "anlatım gerçekleştirme" işlevlerine göre değerlendirilmesi hedeflenmiştir. Alanda bu yaklaşım daha önce taranan kaynaklarda görülmemiştir. Alan araştırmacılarının dil bilgisi ile ilgili çalışmalarına yöntem açısından katkıda bulunulması temel amaç olarak düşünülmüştür.

Çalışmanın kapsamı, Türkiye Türkçesi ile sınırlandırılmıştır. Türkçe dil bilgisi kitapları ve dil bilgisi konuları ile ilgili yapılan araştırmalar da çalışmanın kapsamına dahil edilmiştir. Türkçe dil bilgisinin ses, şekil, cümle ve anlam bilgisi ile ilgili bölümleri, çalışmanın izlediği yönteme göre kapsama alınmışır. Genel olarak çalışmanın kapsamı Türkçenin anlam gösterme ve anlatım gerçekleştirme özelliklerini açıklamaya katkı sunabilecek kaynaklardan oluşturulmuştur.

Bu çalışmanın yöntemi, Türkçe dil bilgisinin temel kaynakçalarının taranmasıyla ulaşılan bilgi ve bulgular aracılığıyla özgün bir yaklaşım ortaya koymaktadır. Yapılan çalışmaların ortaya koyduğu bilimsel sorunların çözümüne katkı sunmak için yeni bir yorum yapılmıştır. Kaynakların benimsemiş olduğu dil birimsel düzenlemeler ve sınıflandırmalar, yeni yaklaşım doğrultusunda eleştirel bir yol izlenerek ve çalışmanın ana problemi doğrultusunda tanzim ve tasnif edilmiştir. Anlaşmayı sağlama aracı olarak dilin birimleşmesinin de "anlaşma"ya göre olması gerektiği ileri sürülüp "anlam gösterme" ve anlatım gerçekleştirme" terimleri, temel kavramlara göre açıklandıktan sonra düzenleme ve sinıflandırmalar ortaya konulmuştur.

Dolayısıyla çalışma, kaynak taraması yoluyla tespit edilen sorunların çözümüne katkı sunmak için kuramsal bir yaklaşım geliştirme denemesi olarak değerlendirilebilir. Bilimsel çalışmaların temelinde veri oluşturma ve sınıflandırma önemli bir yer tutar. Bu çalışma ortaya konulan verilerden hareketle yeni bir yöntem geliştirme girişimi olarak düşünülmelidir.

\subsection{Dil ve Anlam}

\section{Temel Kavramlar}


Dil ile anlam arasındaki ilgi ve ilişki birkaç farklı noktadan değerlendirilebilir. Var oluşlanı bakımından anlam dile mecbur değildir. Dil olmadan da anlam var olabilir. Konuşma ve işitme engelli insanlar dil kullanamazlar, ancak anlaşabilirler. Gerek anlamın işaretlenmesi gerekse anlatımın gerçekleştirilmesi sırasında farklı bir düzgü/düzenek ile anlaşabilirler. Bunun yanında resim, dans ve alet/aygıt gibi insan üretimi, amaçlı olgular da kendi anlamlarını gösterirler. Bundan dolayı her şartta dilin anlam gösterimi geçerli olmayabilir. Ancak, insanın dil etkinliği sadece anlaşmaya indirgenemez, çünkü dil yeterliliği, insan olmanın temel göstergelerinden biridir. Dolayısıyla dil aracilık etmeden de insan zihni, varlık ve olayları damgalama/işaretleme işini gerçekleştirebilir. Dilin var oluşu açısından bakıldığında ise anlam, dilin zorunlu var olma koşuludur. Dil, anlamı işaretleyip taşıyabilmek için temel birimlerinden olan sesi ve sözü var etmek zorundadır. O halde anlam için dil zorunlu değil, dil için ise anlam zorunludur.

Dil ve anlam arasındaki ilişkinin eşit ya da dengeli olması mümkün müdür? Anlam, dil için zorunlu ama dil anlam için doğrudan zorunlu değildir. Bu dilden dile ve dilin kullanım amacına göre farklılık gösterebilir. Dili yaşayanlar ile dili konuşanların dil davranışları bu konuda etkili olabildiği gibi dilin de işlevselliği belirleyici olabilir. Dili yaşayanlar, o dilin dünyasına doğanlardır. Dili konuşanlar/edinenler ise ikinci dil olarak öğrenenlerdir. Ana dili Türkçe olanların anlam gösterimi konusundaki yaklaşımları ile Türkçeyi ikinci dil olarak öğrenenlerin anlam gösterimi konusundaki yaklaşımları farklıdır. Türkçenin anlam gösterimindeki yaklaşımlarından biri her zaman kendisinin söz/kelime üretimi yapmaz, var olan anlam göstericiyi dönüştürerek kullanmaya devam edebilir. Dil ilişkilerini yoğun yaşayan dillerde ödünçleme olarak adlandırllan bu durumda en fazla birimsel geçiş söz/kelimelerde görülmektedir. Türkçenin dünya üzerindeki etkileşim alanları göz önünde bulundurulduğunda etkileşimde bulunduğu dillerden söz/kelime aldığ1 gibi söz de vermiştir. Türkçe sözlükteki isim işlevli sözlerin büyük bir kısmı ilişki dillerinden Türkçeye geçiş yapmıştır. Benzer durum İngilizce için de geçerlidir. İngilizce de etkileşime girdiği dillerden kelimeleri söz kadrosuna dahil etmektedir.

İşlev açısından dil ve anlam ilişkisi her iki taraf açısından da uygun ve verimli bir ilişkidir. Anlamın gösterimi ya da anlatım için en verimli ilisski işlev odaklı olanıdır. Hem anlam hem de dil işlevsel ilişkileriyle birbirine daha fazla yaklaşabilmektedir. Anlam, zihninin doğal davranıșıdır. İnsan olmanın gereği olarak zihin, varlık ve olay karşısında "tepkisel işaretleme" davranışını göstermektedir ve bu anlamın doğasını oluşturmaktadır. İnsanın anlam üretme yetisi yine aynı düzgüye göre anlamlandırma (kavram) ve ses ile işaretleyerek de adlandırma şeklinde gösterilebilir.

Anlamlandırma ve adlandırma davranışları, dil ile anlam arasındaki ayrımı kesin bir çizgiden bulutlu bir alana dönüştürmektedir. Bu dil ve anlam ilişkisinin işlev yoğunluğu ile açıklanabilir. Her adın anlamı olmadığı gibi her anlamın da adı olmak zorunda değildir. Ad/isim ve anlam, dil biliminde sorunlu bir alandır. İsimler, varlıkları ve olayları işaretler ama işaretledikleri varlıkların anlamları hakkında her zaman fikir vermezler. Varlığın ismi, dilin anlam gösterme davranışıyla uyumlu olmayabilir. "doktor" meslek ismi, Türkçe değildir. Türkçenin anlam gösterme düzenine göre "sağaltıcı ya da iyileştirici, şifacı" isimlerinin kullanılması gerekirdi. Ancak Türkçe tercihini "doktor" kelimesinden yana kullanmıştır. "şifacı, sağaltıcı ile doktor" arasındaki anlam ayrımı, alaylı ve okullu eğitime dayanır. Dil, anlamı adlandırır. Bu dil için bir zorunluluktur. Dil birimleri görev paylaşımı yaparken anlaşmanın sağlanmasını esas alır. Bir kısmı anlamın gösterimi işlevini üstlenirken bir kısmı da anlatımın gerçekleşmesini sağlar. Bunun yanında bazı dil birimleri doğrudan anlam gösterme işlevi üstlenirken bazıları da anlatım sırasında anlamın görünürlügüu/anlaşılırlığına etki ederler.

Dilin kendini kendisinden başka imkanlarla oluşturma/gösterme seçeneği yoktur. Ses üretim organlarının yerine vekalet edebilecek başka bir ses üretme imkanı olmadığı için dil kendini konuşma ile gerçekleştirebilmektedir. Bu noktada dil ve anlam ilişkisi, dil ve düşünce ilişkisi üzerinden değerlendirilebilir. Dil ve düşünce ilişkisi, oluşumları bakımından dil, insanın ses organlarında düşünce de beyninde/kafasında/başında gerçekleşmektedir. Düşünce, dili dil de düşünceyi doğrudan etkileyebilirken dil ile anlam arasındaki ilişki hakkında aynı paralellik kurulamamaktadır. Dil, anlama müdahale edememektedir. Dil ve anlam ilişkisinde dilin temel işlevi 
olan “anlaşmayı sağlama”nın bir yanını oluşturan “anlam”ın işaretlenmesi ya da gösterimi, dilin zorunlu temel işlevinin bir tarafıdır. Anlamın aktarılması ya da taşınması -anlatım- ise dilin kendini daha fazla görünür kıldığı işlevinin diğer tarafını oluşturmaktadır. Bu yaklaşıma göre dilin anlamın dışına çıkartılmış olduğu görüntüsü oluşmaktadır.

Dilin anlaşmayı sağlama aracı olması, dili amaç olmaktan uzaklaştırmaktadır. Anlam gösterici dil birimleri bu bağlamda yeniden gözden geçirilebilir. Varlık ve olgular, anlamlarına uygun işaretlenebildiği gibi anlamlarından bağımsız sözlerle de gösterilebilir. Türkçe bu noktada iki temel birimi ile anlam gösterimi sağlamaktadır; söz/kelime ve öbek. Öncelikle varlık ve olgunun dilin evreninde işaretlenmiş/gösterilmiş dil birimi var ise Türkçe bu birimleri kendi söyleyiş biçimine uygunsa olduğu gibi benimsemekte ya da dönüştürmektedir. Dönüştürücü işlemleri ses, söz ve anlam özelliklerine göre gerçekleştirilmektedir. Türkçeye diğer dillerden geçen kelimelerde bahsedilen dönüşümler gözlemlenebilir. Türkçenin öbek ile anlam gösterimlerinde kendi adlandırma sistemini daha etkili kullandığı söylenebilir (Gedizli; 2019b). "şamar oğlanı, dilli düdük, ölüm döşeği, ıvır zıvır, arz talep, kanı bozuk vb.” öbeklerin anlam gösterme özellikleri ve anlatım gerçekleştirme esnasındaki işleyişleri dikkat çekicidir.

\subsection{Dil ve Anlatım}

Dil ve anlatım arasındaki ilişki, dil ve anlam arasındaki ilişkiye göre daha açık bir görüntü sunmaktadır. Dilin işaretleyerek/damgalayarak ortaya çıkardığı ve görünür kıldığı anlam, ses, söz ve öbek sayesinde anlatılabilmektedir. Anlamın işaretlenmesi dilin temel birimlerini adlandırma işlevine yönlendirmektedir. Anlatımın gerçekleşmesi de yine dilin temel birimlerini eylemek/söylemek için görevlendirmektedir. Anlatımın gerçekleştirilebilmesi için dilin temel birimlerinin anlatıcı görevi üstlenmesi gerekmektedir. Fiil/eylem olarak adlandırılan bu sözler/kelimeler bir yanlarıyla anlam gösterirken diğer taraftan da anlama göre işlev kazanmaktadırlar. Hareketi hem gösteren hem de anlatan bu dil birimlerinin temel işlevleri anlatım gerçekleştirmedir. Fiil ile anlatım aynı nitelikleri taşırlar. Anlamın hareketlendirilmesini/anlatımını/söylenmesini sağlayan dil birimleri olan fiiller, dilin temel birimlerini oluşturan ses, söz ve öbeklerden oluşurlar. Her anlam için farklı bir anlatım gerçekleştirici dil birimi görevlendirilmez. Mesela, "uçma" ile ilgili anlam sınırlıdır ama "etme, eyleme, yapma" ile ilgili anlam sınırı çok geniştir. Uçan varlıkların sınırlılığı, "uç_-" kelimesinin de sınırını oluşturur. Yapılan işlerin çok ve yaygınlığı, "yap-" kelimesinin anlatım işlevini artırmaktadır.

Anlatım, konuşma ile gerçekleştirilir. Diğer anlatım araçlarından önce konuşma vardır. İnsanlığın anlam gösterme/işaretleme/resimleme davranışı, yazılı dilden daha eski tarihlere uzanır. İnsanın davranış olarak dili kullanması, insan olmasının gereğidir. İnsansa konuşur, konuşamıyorsa insanlaşmasında (fizyolojik yönden) bir eksiklik vardır. İnsan, anladığı için anlatır. Anlatımın temel vasıtası da konuşmadır.

\subsection{Konuşma ve Anlatım}

Konuşma, insan için hayatta olma göstergesidir. İnsan, konuşmadı̆̆ında insan olarak eksiktir. Susan insanın durumu olağandışıdır. Konuşamayan insan, eksik ve engellidir. İnsanın bilinçli ve amaçlı şekilde susması da bir anlatım/ifade biçimidir. Dilin anlatım ile ilgili birimleri hakkında yapılan incelemelerde konuşma ve konuşmaya bağlı oluşan dil özelliklerinin dikkate alınmaması eksik değerlendirmelere sebep olur. Çünkü konuşma, doğal anlatım biçimidir.

Konuşma, eylem/söylem/fiildir. Konuşmayı gerçekleştirici dil birimleri de eylem nitelikli olmak zorundadır. Konuşma araçları seslerdir. Seslerin amaçlı ve kurallı bir şekilde üretilip bir varlığa dönüştürülmesi konuşma ile mümkündür. Konuşma seslerinin, nefesin dişarıya çıkartılmasıyla üretilmesi, hem konuşmanın hayat göstergesi olmasını hem de anlamın iletilmesini sağlar. Anlamın konuşma dışında ifade araçları vardır, fakat konuşmayı gerçekleştirecek başka seçenekler yoktur. Bundan dolayı konuşma, tek işlevli davranış biçimidir. Konuşma, kendisinden başka bir şey değildir. Aynı tespit ses için de geçerlidir. Ses de kendisinden başka bir şey ifade etmez. /a/, /a/dır. Konuşmanın da özelliği "konuşma" olmasıdır. 
Sesin kendini oluşturması, konuşmanın da oluşmasını sağlar. Her ses aynı zamanda bir konuşma birimidir. Konuşmanın gerçekleşmesi esnasında sesler birimsel özelliklerini gösterirken ses ilişkileri ile konuşulma/söylenme/sesletilme biçimlerini de ortaya koyarlar. Dilin temel birimleri gibi ses birimleri de işaretleyici/gösterici ve ifade ettirici/anlatıcı işlevlerine göre ünlü/vokal ve ünsüz/konsonant şeklinde ayrışıllar. Ünlü seslerin oluşumları esnasında nefes bir kesintiye uğramaz. Ünsüz sesler ise oluşumları esnasında ağızdaki organlar tarafindan kesintiye uğratılırlar. Ünsüz sesler, ünlü sesler aracilığıla söylenir/seslendirilir hale gelir. Seslerin bu şekilde ayrışmaları, işaretleyici ve ifade ettirici özelliklerine göre belirginleşmektedir. Seslerle ilgili bu ayrışma dil birimlerinin isim ve fiil şeklinde ayrışmalarıyla koşutluk göstermektedir. Ünlü sesler ile fiiller, ünsüz sesler ile de isimler arasında var oluş gerekçeleri bakımından ilgi gözlenmektedir.

Konuşma ve anlatım arasındaki ilişkinin anlatımın gerçekleşme biçimlerinin oluşumlanı açısından değerlendirilmesi de mümkündür. Konuşma gerçekleştirilirken seslerin diziliş/sıralanış özellikleri, heceyi esas alır. Elbette heceleme ile anlatım arasında doğrudan bir ilişki kurulamaz, ancak anlam gösterici birimlerin anlatım gerçekleştirme düzenine göre düzenlenişi konuşana/anlatana göre biçimlenir. Seslerin dizilimleri ile anlatım birimlerinin düzenlenişi sıralanışları bakımından benzerlik gösterse de her ikisinin işleyişleri kendilerine göre iç düzenleme oluşturur. Ses dizilimi söz/kelime/anlam gösterici oluşumlarını gösterirken, kelime dizilimi anlatım düzenini kurar. Bundan dolayı konuşmanın seslendirme kısmı ses işletimi ile ilgili özellikleri gösterirken, anlatım kısmı da söz işletimi ile ilgili özellikleri yansıtmaktadır. Nefes boğumlanmalarıyla işaretlenen/oluşan sesler, konuşma esnasında söze/anlama ve söyleyişe/anlatıma göre boğumlanmaktadır/düzenlenmektedir.

Anlam ve anlatım, konuşmanın amacı, bağlamı ve gerekliliğine göre dönüşümler yaşayabilir. Konuşmada her zaman muhatap bulunmak zorundadır, ancak konuşmada amaç, bağlam ve gereklilik değişkenlik gösterebilir. Temel anlatım birimi olan cümle ile ilgili değerlendirmelerde, anlatım ve konuşmanın özellikleri göz önünde bulundurulmalıdır. Anlatım bildirme, bilgilendirme, yönlendirme ve bildirilme, bilgilendirilme, yönlendirilme amaçlarına göre gerçekleşebilir. İhtiyaca yönelik de gerçekleşen anlatım beklenti, soru-cevap, uyarı şeklinde olabilir. Anlatımın her noktasında göz ardı edilmemesi gereken husus, bağlamdır. Bağlam işaretleyici unsurlar anlatıcı, anlam, zaman, yer ve nitelik gibi unsurlardır. Dilin temel birimleri ses, söz/kelime ve öbekler anlatım/konuşma esnasında bağlam belirleyici işlevler üstlenirler. Her dil kendine göre bağlam belirleyici unsurlar oluşturur. Türkçenin de bağlam belirleyici unsurları anlam gösterme ve anlatım gerçekleştirme düzenine göre ya doğrudan bu görevler için oluşturulmuş birimlerle ya da anlam ve anlatım ilişkisine göre dönüşümlerle ortaya çıkmaktadır.

Anlatımın temel unsuru olması bakımından bağlam oluşumunu sağlayan birimlere değinmek gerekir. Anlam ve anlatım bağlayıcılar olarak iki başlık altında gösterilebilecek olan bu dil birimleri, kelime ve öbek birimlerden oluşmaktadır. Kelimelerin göstermiş oldukları anlam ilgisinden dolayı oluşan bağlam birimleri öbekleşirler. İkileme olarak adlandırılan öbeklerin bir kısmı anlam ilgilerinden dolayı bağlam işaretleyicilerdir. İşlevleri bakımından işaretledikleri varlıkların ortak özelliklerine göre bağlam oluşturan birimler de öbekleşirler. Anlam ve işlevleri bakımından ilgisi olmayan kelime ve öbekler arasında anlam ve anlatım ilgisi ve ilişkisi kuran kelimeler de bağlam oluşturucudur. Öbekleşme yoluyla anlam gösteren ve anlatım gerçekleştiren bağlam unsurları da vardır. Ekler aracılı̆̆ıyla da bağlam oluşturulmaktadır. Bazı ekler anlamda bağlam oluştururken bazıları da anlatımın bağlamını kurarlar. Dil bilgisinde sıfat fiil ve zarf fiil olarak gösterilen ekler bağlam oluşturucu eklerdir. Sıfat fiil ekleri anlam gösterme, zarf fiil ekleri anlatım gerçekleştirme işlevlerinde bağlam oluştururlar. Aynı bağlamda birden fazla olayın/eylemin anlatılabilmesi için dilin anlam gösterme ve anlatım gerçekleştirme düzenine girişleri ekler aracıllğıyla sağlanmakta ve bağlamdaki yerlerini almaktadırlar. Anlatım ve bağlam arasındaki ilişki çok yönlü bir görüntü sunmaktadır ve her ilişki seviyesi farklı bağlamlarda değerlendirilebilir.

\subsection{Dil ve Söz}


Dil ve söz arasındaki ilgi ve ilişkinin mahiyeti bir yanıyla anlama diğer yanıla da sese yaslanmaktadır. İlginin anlamla ilişkinin de ses ile sağlandığı şimdilik bir varsayım olarak kabul edilebilir. Zihnin anlam oluşumundaki ilk davranışı yukarıda tepki ya da uyarı olarak belirtilmişti. Zihnin tepkileri arasındaki ilgi ve ilişkinin kavramlaştırmayı, kavramların dilin sistemine geçişinin de söz ile sağlandığı ifade edilmişti. Bu durumda sözün anlamı dilselleştirdiğinden bahsedilebilir. Anlamın dilin evrenine geçişi, hem dili hem de anlamı sözde birleştirmektedir. Söz, zihin; anlam ve dil açısından yeni bir etkinlik alanı oluşturmaktadır; düşünce.

Düşünmek, salt zihin etkinliğidir. Bağlamsal bir işleyiştir. Düşünmek, eylemdir. Eylemin sonucu, bir varlık olarak düşünceyi ortaya çıkarır. Düşüncenin dünya ile ilişkisini dil kurmaktadır. Dilin düşünce ile ilişkisi varlık ve olgularla değil, dilin temel birimi olan söz/kelime ve öbek ile gerçekleşmektedir. Kelime ve öbek, düşünme faaliyetine işaretledikleri anlamların temsilcileri olarak katılırlar. Dil birimlerinin düşünme faaliyetindeki tek işlevleri işaretleyici/gösterici/isim olmalarıdır. Özel bir işareti/göstericisi/ismi olmayan "im/iz, şey, a piori ya da x" olarak belirtilir. Düşünmek, olanlarla olmayanları oldurur. Bundan dolayı dil, düşünceye olanı (im, şey, x) sunar, düşünce de onlar aracilığıly olusturur, oldurur, oldurtur, olunur ya da imler, imlenir, imleşir, imletir, imlettirir. Türkçede /i/, ses; i-, fiil; i-m/ i-z, isim/sözdür. Dil ve söz arasındaki ilişki, düşünceyi; düşünce de anlam/değer üretimi ve anlatım gerçekleştirimini etkiler. Dilin anlatım özellikleri ve anlatım biçimleri, dilin düşünme sistemine göre şekillenir ve bu da dilin diğer dillerden farklılaşmasını belirler. Ancak bu ilişki birimsel değil, ilgisel bir bağlamda değerlendirilebilir.

İlgi, şeyler arasında doğrudan olabildiği gibi dolaylı olarak da oluşturulabilir. "Tekeden süt çlkarmak" sözü Türkçenin ürettiği bir deyimdir. "Olması olas1 olmayanı oldurmak" anlamını gösterir. İlgi, bazen zorunlu bazen de keyfi bir bağlllıkttr. Gerek sözün var oluşu gerekse dilin var oluşu açısından karşılıklı zorunluluk, onları bir bütün olarak tek bağlamda göstermektedir. Dili sadece sese ya da söze indirgeyerek değerlendirmek veya sözü anlam ve sese indirgemek de dilin bilgisini doğru ve tutarlı bir şekilde kurgulamaya yetmemektedir. Türkçe öğrenenlerin amacı sadece konuşmak değil, Türkçe ile düşünebilmektir.

Dil biliminin ilgi alanı dışında dil ve söze etki eden pek çok bilgi alanı bulunmaktadır. Psikoloji ve sosyolojinin bilgi alanını oluşturan insanın bireysel ve toplumsal davranışları, insan ve toplum için araç-varlık olan dili ana-varlık ya da amaç-varlık haline getirmektedir. Bundan dolayı dil, anlaşma aracı olduğu toplumun kimliğini oluşturmaktadır. Bu kimlik insanın mensubu olduğu toplumda kişileşmesini sağlar. İnsanın kişiliğinin gelişimi ve yeterliliğinde konuşma ve anlatım becerisi temel ölçüttür. Dil ve söz ilişkisi anlaşılır ve açıklanabilir bir ilgi ile bağlam kazanırsa "dilin sözü ve sözün dili” ile ilgili Türkçenin bengü bilgisi de ortaya çıkarılmış olur.

\section{Türkçenin Birimleşme Düzeni}

Dil bilgisi açısından bir karşıtlık oluşturan “dil ve söz”, dünyayla ilişkisini Türkçe ile kuranlar açısından bir bütünlük oluşturmaktadır. Ses ve sözün anlamı işaretlemesiyle oluşan dil, dil bilgisinde bu iki unsuru temel birim olarak konumlandırmaktadır. Türkçede iki türlü birimleşmeden söz edilebilir; dilin karakteristik özelliğinden kaynaklanan doğal birimler ve dil bilgisinden dolay1 belirlenen bilgisel birimler. Bu birimler Türkçenin işleyişini gözlemlemeye yardımcı olmaktadır.

Türkçenin doğal birimleri ses ve anlam, yani konuşmadır. Anlam, Türk aklının varlık ve eylemin uyarıcı etkisine karşı verdiği tepkiyi sesle imleyip söz olarak göstermesidir. Söylenebilirlik/sesletim ve anlaşılabilirlik/uzlaşı, Türkçede doğal birimlerin amacıdır. Gerek Türk tarihi gerekse Türk dili tarihinin ortaya koyduğu bilgiler bu ilginin oluşumunu göstermektedir. Geniş bir coğrafyada, çok farklı dil ve milletle yaşayıp kendi dilinde dünyayla ilişkisini sistematik destek unsurları (eğitim, yazı vb.) olmadan sürdürmek Türkçeye özel yetenekler kazandırmıştır. Söylenerek/konuşularak var olmak, Türkçenin sözlü dil kimliğini pekiştirmiştir. Dilin araçlık vasfi gelişirken sözün niteliği de yücelmiştir. Çağatay ve Osmanlı Türkçesi dönemi metinlerinden Türkçeye ait unsurlar (ekler ve kelimeler) çıkartılırsa geriye Türkçeden ne kalır?

Türkçenin dil bilgisel birimleri ise ses ve söz/kelime zeminine göre biçimlenir. Dilin doğal birimi olan ses, dil bilgisinde de temel birimdir. Seslerin ilgi ve ilişkisiyle bir araya gelerek 
Gedizli, M. (2021). Türkçenin anlam gösterme ve anlatım gerçekleştirme düzeni. Journal of Human Sciences, 18(3), 400-430. doi:10.14687/jhs.v18i3.6195

oluşturdukları birim ise sözdür. Söz, dilin en çok iş gören birimidir. Sözün oluşumunda seslerin bir araya gelme kuralları vardır. Bu kurallar dilden dile farklılık gösterir. Sözlerin bir araya gelerek oluşturdukları birim ise öbektir. Türkçe dil bilgisi kitaplarında öbekler farklı terimlerle gösterilse de sonuçta en az iki sözün bir araya gelmesiyle oluşturulan temel dil birimidir. O halde Türkçe dil bilgisi üç temel birim üzerinde şekillenmektedir; ses, söz ve öbek.

Türkçenin "anlaşmayı sağlama” işlevi, ses, söz ve öbek birimleri ile gerçekleştirilmektedir. $\mathrm{Bu}$ temel dil birimleri, Türkçenin anlam göstermesini ve anlatım gerçekleştirmesini de sağlamaktadır. Türkçedeki ses, söz ve öbek birimlerinin aralarında eş değerlilik vardır. Var oluş sebepleri "anlaşma sağlama" aracı olan dilin ihtiyacı olan her türlü dil unsurunu temin etmektir. İsim, fiil, zamir, zarf, ünlem, edat, ek, ikileme, deyim, cümle vb. dilin işleyişini sağlayan ve ihtiyaç durumunda üretilip devreye sokulan dil birimleri, ses, söz ve öbek birimlerinin alt birimlerini oluşturmaktadır.

Türkçe dil bilgisi kitapları söz ve öbek konusunda karmaşık bir görünüm sunar. Söz için kelime ve sözcük terimlerini kullanır ve bunun tanımını yapmakta zorlanır. Kelimenin tam olarak tanımlanmasının zor olma gerekçesi olarak da diğer dillerdeki tanım belirsizliklerine atıfta bulunur. Kelime/sözcük için belirsizliğin temelinde "anlamlılık" konusu yatmaktadır. Kelime anlamlıdır ama doğrudan anlam göstermeyen ancak anlam gösteriminde ya da anlatım gerçekleştiriminde rol oynayan bu terim kelime tanımını geçersiz kılmaktadır. Bunlara "edat" denilir ve "anlamı olmayan görevli" kelime olarak açıklanır. Dil bilgisi kaynaklarının tespitleri yerindedir ancak onların kelime/sözcük ile ilgili yaklaşımının sorunu Arapçanın kelime tanımını esas almalarıdır.

Türkçede anlamın çok farklı işaretleme yolları vardır. "buzağı" için "yavru inek", "horoz veya tavuk" için "erkek tavuk ve dişi horoz" şeklinde işaretlemeler yapılarak sadece bir birim zorunluluğu yoktur. "horoz" için "erkek tavuk" denilmesi yanlış değildir. Anlam da yerli yerinde durmaktadır. "kitap, kitap+cl, kitap+lık, kitap+l, kitap+sız, kitapcl+llk" örneklerinde "kitapcl; kitap satan, kitapllk; kitap konan dolap, kitapli; kitap sabibi olan, kitapsız; ralim, acımasız, insafsız, kişi, kitapçllk; kitap satısı yapan meslek" anlamlan işaretlenmektedir. "kapr kolu, kapı mentessesi, kapr rill, kapr altr, kapr kilidi, kapı önü, çelik kapı, ahșap kapı, arka kapı, dış kapı vb." örneklerinde "kapı kolu; kapry açp kapamak. için elle tutulan parça, kapı menteşesi; kapımm dwvara bağlanmasm sağlayan düzenek, kapr zili; ev, apartman ve bahce gibi yapularn ana giris kapularmm üzerinde bulunan ve içeridekilerin duyabileceği bir yere sabitlenen zill, $v b$." işaret edildiği gibi anlam gösterimi sağlanmaktadır. "Damlaya damlaya göl olur, sakla saman gelir zaman, el elin eseğgini türkü ç冖̆grarak arar, bir elin nesi var iki elin sesi var" gibi atasözlerinde

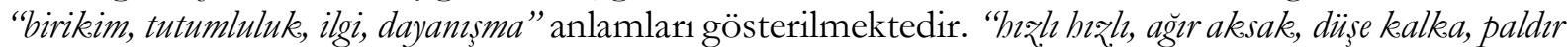

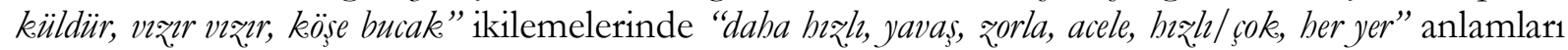
gösterilmektedir.

Anlamın anlatımı için dil dışında da yol ve yöntemler vardır. Zihinsel bir etkinlik olan anlam, farklı uygulamalarla kendini gösterir. Dil ile anlatım insan için tek doğal ve işlevsel yoldur. Diğer anlatım yollarının işlevselliği ve doğallığ1 yoktur ve belli amaçlar için tercih edilmektedir. Resim, dans, mimari, heykel ve mimikler de anlamın gösterimi ve gönderiminde kullanılmaktadır. Dünyanın en yüksek binası, emojiler, tablolar vb. unsurlar sadece kendisi değil, kullanıldığı mecra içinde mesaj da vermektedirler.

Dil ile anlatımın temel birimlerinden biri cümledir. Cümle, bildirimde bulunan dil birimidir. Fiil cümlenin temel/kurucu unsurudur. Söz/kelime olarak fiil, isim şeklinde bulunur. Fiil türü kelimeler, kullanıma girdiklerinde kişi/fail/özne ve zaman veya durum işaretlemek zorundadır. Anlam gösteren dil birimleri cümlede fiil tarafindan yönetilir ya da fille ilişkilidir. Cümleyi oluşturan özne, nesne, zarf ve dolaylı tümleç/yer tamlayıcısı doğrudan yüklemle ilgi ve ilişki kurar. Yüklemle birimler arasındaki ilgi ve ilişki doğrudan kurulamadığı durumlarda bu görevi üstlenen birimler/ek, bağlaç ve ilgeçler (son çekim edatları) devreye girer. Türkçe dil bilgisi kitaplarının genel olarak belirttiği bu açıklamalar, Türkçenin anlatım düzeni açısından cümlenin de kelimede olduğu gibi "içerik (kapsam-bilgi)" sorunu olduğunu göstermektedir. Arapça olan "cümle" kelimesi, "bütün, tüm" anlamlarına gelmektedir. Türkçede her cümle yarg1 bildirmez, ancak dil bilgisinin temel kaynakları cümleyi "yargı bildiren” kelime dizisi olarak nitelendirmektedir. Anlatımın temel işlevi, 
Gedizli, M. (2021). Türkçenin anlam gösterme ve anlatım gerçekleştirme düzeni. Journal of Human Sciences, 18(3), 400-430. doi:10.14687/jhs.v18i3.6195

anlaşmanın sağlanmasına araçlık etmek ise bu her durumda yargi içermesini gerektirmez. Anlatımın sona erdiği, konuşmada susarak ya da ara vererek; yazıda ise nokta konularak gösterilir. Türkçenin anlatım özellikleri ve biçimleri, cümle bilgisinin kalıplarıyla örtüşme sorunu yaşamaktadır. Anlatımın temel belirleyicisi "bağlam"dır. Bağlam anlam ilişkilerini kurduğu gibi anlatımı da ilişkiye katılan anlam gösterici ve anlatım gerçekleştirici unsurlara göre şekillendirmektedir. Bu konuda Türkçenin temel birimlerinin betimsel özelliklerinden çok işlevsel özelliklerine göre tanzim ve tasnif edilmesi gerekmektedir. İsim, fiil ve edat olarak oluşan doğal dil birimleri, işlev ve dönüşüm özelliklerine göre dil bilgisel birimler olarak sınıflandırılabilir. Temel birimlere göre isimler, fiiller ve edatlar değerlendirildiğinde bağlam kurucu, anlam gösterici ve anlatım gerçekleştirici özelliklerin gözlemlenmesi, anlatım hakkındaki sorunları cümlenin kurallarına göre değil, Türkçenin anlatım özelliklerine göre değerlendirme imkanı sunabilir. Sonuçta her dil kendine özgü bir anlatım sistemi/düzeni/kurgusu vardır.

Türkçenin cümle sisteminde ana unsur yani fiil dizilişte en sondadır. Türkçe konuşanlar önce anlamı işaretler, sonra bildirimde bulunurlar. Yüklemin her zaman söz diziminin son unsuru olması zorunlu değildir. Genel ve yaygın anlatımda yüklem sondadır ve en son söylenir. Konuşurken sonda bulunan yüklem, yazılı anlatımda metnin maksadına göre cümle ögelerinin sıralanışında yer değiştirebilir. Türkçe dil bilgisi kitaplarında yüklemi cümlenin sonunda olmayan cümleye "devrik cümle" denilmektedir. Yüklemin yer değişiminde keyfiyet değil amaç vardır. Vurgulamak, dikkat çekmek, şaşırtmak gibi anlatımın türü ve amacına göre yüklem yer değiştirir. Cümlenin diğer unsurlarının gösterdiği anlama zarar vermeden cümle unsurları yer değişikliği yapabilir. Bu, Türkçenin anlatım özelliklerinden biridir.

Türkçede cümle, birimsel olarak tek ses, tek söz ve tek öbekten oluşabilir. "Aaa!, Eee!" ünlemleri "Aaa!; şşşrdim, Eeel; devam et, sonra ne oldu?" cümleleri dil davranışlarıdır ve bildirimde bulunmaktadır. "Düsmeyeceksiniæ: Dinlendim. Öğretmenim. Türkşeleștirebilirsiniz:" kelimeleri "Siz. düsmeyeceksiniæ. Ben dinlendim/yorgunluğum bitti. Ben ögretmenim. Siæ. Türkçenin kurallarna uygun hale

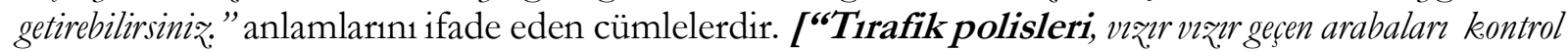
etmedi. (kim, neyi). Uzun boylu adamin yerden bitme karıs1, ilk kocasmdan küüük kizına, kendi babasinın yüzüğünü por pir eden yürek, çarpintısyyla hediye etti. (kim, kime, neyi, nasıl)'] cümlelerinin her bir ögesi öbeklerden oluşmaktadır.

Söylenmiş/anlatılmış her söz/anlam, bir anlam gösterir. Bundan dolayı cümle anlatım gerçekleştirdikten sonra bir anlam göstericidir. Türkçede bir cümle bir başka cümlenin ögesi olabilir. Cümlenin cümle ögesi olması, onun cümlelik hükmünü kaldırır. Cümlenin içinde cümle olamaz. 'Bana 'orada duramåssm' dedi” (kim, kime, ne) cümlesinde 'orada duramazsın' öbeği, cümlenin nesnesidir.

Türkçede genel olarak bütün dil birimleri anlam gösterme ve anlatım gerçekleştirme işlevini yerine getirirken "ses, söz ve öbek" temel birimleri, dilin temel işlevi olan anlaşmanın sağlanmasına katkıda bulunacak şekilde biçimlenir. Türkçe dil bilgisi kurgusunun "ses, söz ve öbek" temel birimleri dikkate alınarak düzenlenmesi, pek çok dil bilgisi ihtilafının ortadan kalkmasına katkıda bulunabilir.

\subsection{Ses ile Anlam Gösterme}

\section{Türkçenin Anlam Gösterme Düzeni}

Türkçede dil sesleri ve doğadaki bütün sesler, anlam işaretleyicisi olabilir. Sesin, anlamı işaretlemesinden dolayı isim türü sözcükler gibi de işletilir. Ses Türkçenin temel dil birimidir. Ses düzgüsü/sistemi dilin öz kaynağıdır. Türkçenin ses düzgüsü Türkçeye göre biçimlenmiştir. Dilin oluşturduğu ses düzgüsü rastgele değildir. Her ses, dilin temel bir birimi olarak dilin temel işlevine doğrudan katkıda bulunur. Söyleyişte: "Ce, Türk alfabesinde üçüncü sirada gösterilir. Ce'nin săğndaki e sesi alfabede gösterilmez: Ce'den sonraki ses de'dir. De'deki e'yi de alfabede göremezsin. Türkscenin sesleri alfabede tek isaretle gösterilir. Bunlardan sekiz tanesi kendinden sonra e sesi istemezyirmi bir tanesi de e'ye mecburdur. E'nin görevi săg bitisiğgine geldiği sesin söylenisini sağlamaktır." Metinde: "/ c/ Türk alfabesinde üsüncü sirada gösterilir. 
Gedizli, M. (2021). Türkçenin anlam gösterme ve anlatım gerçekleştirme düzeni. Journal of Human Sciences, 18(3), 400-430. doi:10.14687/jhs.v18i3.6195

/c/'nin sağmdaki /e/ sesi alfabede gösterilmez: ... “ Örneklerde görüldüğü gibi Türkçede ses anlam göstermektedir. Sesin gösterdiği anlam kendisidir.

Türkçe dil bilgisi kitaplarında yansıma seslerle oluşturulan kelimeler olarak bahsedilen dil birimleri pek çok söz varlığı oluşturmaktadır. "tak-ırtı, pat-ırtı, şap-lak vb.” örneklerde görüldüğü gibi ses olduğu gibi alınıp Türkçenin dil sistemine dahil edilmiştir. Yansıma sözcükler olarak adlandırılan bu birimler kök olarak birden fazla ses ile işaretlendikleri için doğrudan söz/kelime olmaktadırlar. Kuş sesi "cik", köpek sesi "hav", koyun sesi "me", düşük ses tonu "fis", tahtaya vurunca çıkan ses “thk. (yavas)/tak (normal)", saat sesi "tiktak" gibi örnekler Türkçede bolca görülmektedir. "cikle-, havla, mele-, fiskos, tıkırtı, tiktak”" örnekleri de bu seslerden türetilen kelimelerden bir kısmıdır.

Dil sesleri öncelikleri kendi anlamlarını gösterir. Sesin anlamı kendisidir. /a/ veya /y/ sadece kendisini gösterir. Doğadaki sesler veya hayvan sesleri ise sesi üreteni işaret eder. Yukarıda dil seslerinin sadece dil için üretilen sesler ve tek amacının da dilin anlaşmayı sağlama işlevini yerine getirmek olduğu belirtilmişti. Seslerin hem kendi hem de dilin düzeni için geliştirdikleri kurallar vardır. Sesler, özellikle kelimelerin oluşumunda anlamın gösterimini doğrudan etkilemektedirler.

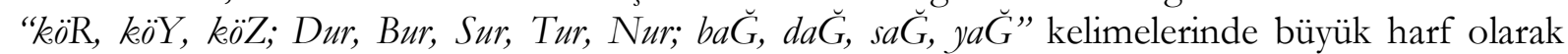
gösterilen sesler anlam belirleyicidirler. Türkçe kelime başlarında iki ünsüz ses yan yana, kelime içinde de iki ünlü ses yan yana bulunmaz. Türkçenin kelime bilgisini göstermesi bakımından "spor, kral, plan; daire, daima, sual" gibi kelimelerin Türkçeye diğer dillerden geldiğini gösterir ancak bu kelimelerin söyleyişinde ve sesle hecelenmesinde Türkçenin sesletimi uygulanır. "sı-por, ki-ral, pi-lan; da-i-re, da-i-ma, su-al" şeklinde heceleyerek söylenir. Bu çalışmanın kapsamı dışında olmakla birlikte, diller arası geçiş yapan kelimeler, dahil oldukları dilin ses kurallarına göre değişime uğrarlar. Dilin ses kurallarına uyum sağlamayan ve ait olduğu dilin ses kurallarına göre seslendirilen kelimelerin nicelik bakımından artması, dahil olduğu dilin ses düzenini ve niteliğini aşındırır. Hatta dilin kendi seslerini de etkileyip dönüştürebilir.

Türkçenin kelime varlı̆̆ının önemli bir kısmı diğer dillerden geçiş yapmıştır. Özellikle isim türü kelimelerin önemli bir kısmı etkileşime girdiği dillerden geçiş yaparken Türkçeden de diğer dillere geçiş yapan pek çok kelime bulunmaktadır. Türkçeye geçen kelimeler, geldikleri dillerdeki ses özelliklerinden ve anlam gösterme işlevlerinden uzaklaşıp Türkçenin sistemine göre dönüşmüşlerdir. Dönüşüm, Türkçenin temel işletim özelliklerinden biridir. Bu çalışmanın kapsamında olmamakla birlikte, kısaca dönüşüm ile ilgili şu noktaya değinmek gerekir. Türkçenin eklileşme özelliği, birimleri doğal bir dönüşüme uğratmaktadır. Temel birimler, bağlama uygun şekilde farklı işlevlerde kullanılabilmektedir. Türkçede varlık adı, kişi adı olarak kullanılabilir; “Demet, Yaprak, Yağmur, Seher, Yıldır.vb.". İsim, fiilleşebilir; fiil isimleşebilir; ek veya ses kelime kökü olabilir; "su+la-, yap-l, +Ci'nın kullanm ve / $/$ /nin özelliği vb.". "Aişe/Aysse, Mubammed/Mubammet, sabr/sabır, fikr/fikir vb." örnekler de Arapçadan geçiş yapan kelimelerdeki dönüşümleri göstermektedir. Türkçenin ses havuzunda olmayan bir sesi karşılamak için Türkçe geçiş yapan kelimenin ses özelliğine en yakın olan sesi tercih etmektedir. Arapçada "sin, sad, peltek se" üç farklı sestir, Türkçe bu sesleri /s/'ye dönüştürmektedir.

\subsection{Söz ile Anlam Gösterme}

Anlamın söz/kelime ile işaretlenmesi genel olarak dillerde yaygın olan yoldur. Türkçenin anlam gösterimindeki rolünden ve Türkçe dil bilgisi kitaplarındaki kelime/sözcük ile ilgili kargaşadan dolayı bu çalışmada söz kelimesinin kullanımı tercih edildi. Söz, anlamı amaçlı ve değerli bir varlık olarak sese dönüştürüp Türkçenin işleyişine ve ilkelerine göre öbekleşmeyle oluşan temel dil birimidir. Sözün temel işlevi dilin anlaşma sağlama işlevini gerçekleştirmesine katkı sunmaktır. Genel olarak bütün dillerde temel dil birimini söz oluşturur. Dilin dünyasından söz çıkartılırsa (farazi olarak) geriye hiçbir şey kalmaz. Dil ile ilgili her türlü çalışmada söz, konunun merkezinde yer alır. Zaten söz olmadan dil denilen varlığın mümkün olması düşünülemez. Dil araştırmalarının temel sorunu sözün/kelimenin "anlam" olduğu kabulüdür. Gerek anlam bilimi araştırmaları gerekse anlamla ilgilenen diğer bilim alanları, "anlam"1 doğrudan dille ilişkilendirmeye temkinli yaklaşmaktadırlar. Dilin bütün birimleri söz niteliğindedir. "Söz" olma vasfi kazanamayan ses, 
anlam, davranış ve varlık dilin işleyişine/evrenine katılamaz. Zihnin düşünce etkinliğinden geçerek var olan söz, tamamiyla dille var olan bir temel birimdir.

Anlam ve zihin ile ilgili çalışmalar son yıllarda artmaya başlamıştır. Farklı disiplinlerin işbirliği yaparak ortaya koydukları incelemeler, insan zihninin uyku hali de dahil olmak üzere kesintisiz şekilde faaliyetlerini sürdürdügünü göstermektedir. Rüya, sanr1, bellek ve unutma gibi zihinle doğrudan ilgili olduğu düşünülen ve araştırmalarda kesin bir hüküm ortaya konulamasa da konuyla ilgilenenler açısından herkesin bu konuda en sağlıklı yol kişinin kendi tecrübeleridir. Beyin organıyla ilgili yapılan gözlemler, beyin ve zihin arasındaki ayrımı ortaya koymuş ve bilinç ile ilgili merakı tetiklemiştir. Bilinç, bir taraftan zihnin işleyişiyle ilgilenirken diğer taraftan dilin bu süreçteki rolünü incelemektedir. $\mathrm{Bu}$ yaklaşımlar, insanlık tarihinin ortaya koyduğu bilgi birikimlerinin sonucudur. Bilişimin insan hayatının her aşamasında yer bulması, "logos/söz"ü yeniden düşünmeye mecbur bırakmıştır. Varlık ve olaylar hakkında katedilen mesafe, zihnin onlar ile ilgili "tepki/uyaran" niteliklerini de dönüştürmüştür. Dil bilgisinin de bu dönüşümlere göre kendisini gözden geçirmesi gerekmektedir.

Dil ve anlam arasındaki ilgi ve ilişki, dilin anlaşmayı sağlama işlevi üzerinden bu çalışmaya konu olmaktadır. Dil mi anlamı, anlam mı dili üretir? Dil mi anlamı, anlam mı dili yönetir? Felsefe, bu konularla ilgili bilinen tarihi içinde pek çok sorgulamalar yapmıştır ve devam etmektedir. Dil araştırmacılarının konuyla ilgili çok fazla tartışması yoktur, çünkü dilin eldeki veriler üzerinden incelenmesi, dil hakkında daha fazla bilgi edinmeye yardımcı olabilmektedir. Felsefeden sonra antropoloji, sosyoloji, psikoloji, pedagoji ve nörolojinin de konuya ilgisi, dil bilimcileri de harekete geçirmiştir. Özellikle dil bilimi ve dil bilgisinin etki ya da ilişki alanlarının genişlemesi, mevcut dil bilgisi kitaplarının tanım, tasnif ve açıklamaları yeterli olamamaktadır. Bu çalışmanın da amaçları arasında "yapay zeka, yabancı dil olarak Türkçenin öğretimi ve Türk aklının imkanı, imarı ve inşası vb." açısından meselelere katkı sunmak da vardır. Türkçenin anlam ile ilişkisi ve anlaşmayı sağlama işlevindeki araç birimlerinin başında gelen "kelime/sözcük/söz" ile ilgili kuramsal tartışmaların bir döngüye girmiş olması, Türkçenin birimleri ile ilgili sorunların çözümünü ertelemektedir.

Dilin anlaşmayı sağlama işlevi, dilin oluşumuna ve işleyişine katkı sağlayan birimlerle gerçekleşmektedir. Bu yaklaşım dilin doğal birimlerine göre oluşturulmuş bir düzenlemedir. İsim, fiil ve edat olarak belirtilen bu düzenleme, dilin doğal sisteminin temel işlevsel birimleridir. Dil, birimlerini dilin temel işlevine katkısındaki rollerine göre bir yapılanmaya yönlendirir. Özellikle kelime gibi dilin temel kurucu/oluşturucu/işletici birimi, sadece "anlamlıllk" esasına göre derlendirildiği için anlamlı olmadığı belirtilen ek ve edat gibi birimler, Türkçe dil bilgisi kitaplarında işlevlerine göre adlandırılır ve kelime olarak değerlendirilmezler. Halbuki bu dil birimleri de söz/kelime işlevlidir ve dilin temel işlevini gerçekleştirmeye katk1 sunarlar. Dilin bilgisi, dilin işleyişine göre kurgulanır. Diğer varlıklar için de geçerli olan bu genelleme, özellikle insan ve toplum bilimleri ile ilgili alanlarda "kültür" unsurundan dolayı daha fazla önem kazanmaktadır.

Kültür biliminin dil bilimi ve dil bilgisine sağladığı en önemli imkanlardan birisi, "her dilin anlaşmayı sağlama görevini 'kendince' yerine getirdiğini” tartışma ortamı sunmasıdır. Dilin diğer işlevlerinden birisi de insan ve toplumun söylemle ilgili davranışlarını düzenlenmesidir. Türkçe yaşayanlar, dünyayla ilgi ve ilişkilerini Türkçe aracıllğıyla kuranlar ya da ana dili Türkçe olanların "kalıp sözler kapsamında değerlendirilen tanışma, teşekkür ve vedalaşma vb." ile ilgili çok farklı anlaşma kalıp sözleri veya kalıp bağlamları kullandıkları gözlemlenebilir. Bundan dolayı dil bilgisi kitapları, dilin bilgisini dilin gerçekleşimine uygun şekilde kurgulamak durumundadır. "Hele bir gelsin de bakalım, ile Hele bir yapsin da görelim, veya Bak hele, Abmet! ve Bak hele Recep (Ege bölgesi ağrqlarnda 'bakale'), mahallenin bakkkalıdrr." anlatımlarında/ifadelerinde "hele" sözü/kelimesi, anlaşma aracı olan dilin anlam gösterme/işaretleme gerekçesine göre anlatım düzgüsünde görev almaktadır. "hele" kelimesi bu anlatım birimlerinde kullanmadığında "anlam"ın istenildiği gibi anlatılamadığı/anlamın taşınamadığ1 fark edilir. Bu durum Türkçe dil bilgisinde açıklanmalıdır ve "hele" kelimesi sadece bağlaç başlığı altında değerlendirilmesi eksik bilgiye sebep olmamalıdır.

Türkçede söz/kelime, sözün anlam gösterme işlevinden dolayı kendinden bağımsız ancak işlev bakımından kendisine zorunlu bağımlı “sözcük/ekler”ler üretir. Ek olarak adlandırılan bu söz 
formunun söz ile ilişkisi ses-söz ilişkisine benzer bir niteliktedir. "söz parçacığ1, söz alt birimi, söz kırıntısı vb." öbeklerle gösterilen bu dil birimleri; ses, söz ve öbek kadar dilin işleyişinde etkili olmaktadır. Bu çalışmada "söz/kelime" ile doğrudan ilgi ve ilişkisi olduğundan dolayı bu bölümde ele alınmaktadır. Çünkü "sözcük/ek/söz parçası/söz alt birimi/söz kırıntısı" olarak adlandırılabilecek bu dil birimlerinin "söz/kelime" ile ilgi ve ilişkisi ses-söz ilişkisine göre zorunlu bağımlı bir ilişkidir. Çalışmanın kompozisyonuna halel getirmemek için Türkçenin bu temel birimi ile ilgili "söz ile sözcük" ilgi ve ilişkisi şeklinde bir adlandırma tercih edilmek zorundadır. Türkçe dil bilgisi kitaplarının "kök/gövde-ek" olarak adlandırdığı bu dil birimleri, meram hasıl olana kadar "söz-sözcük" șeklinde adlandırılacaktır.

"söz+cük", +cUk ekinden dolayı "küçük söz" anlamını göstermektedir. Diğer taraftan "gelin+cik" örneğinde olduğu gibi hem bitki hem de hayvan ismi olan "gelincik" sözü/kelimesi gibi "gelin"kelimesinden bağımsız düşünülerek türetilmiş de olabilir. Kuvvetli ihtimal olarak "söz" kelimesinin Türkçedeki anlam gösterme işlevi konusundaki yaygın etki alanından ve kelime kelimesinin yerine ikame edilmek istenmesinden dolay1 "sözcük" kelimesi türetilmiştir. Konu, çalışmanın doğrudan kapsamında olmadığı için ayrıntıya girilmeyecektir. İlgili kaynaklarda ayrıntılı bilgiler mevcuttur.

"söz-sözcük" ilgi ve ilişkisi, dil açısından bir yanıyla anlam gösterme diğer yanıyla da anlatım gerçekleştirme işlevlerinden dolayı çift yönlü şartlar göz önünde bulundurularak incelenebilir. Türkçe dil bilgisi kitaplarında yapım/türetim ve çekim/işletim ekleri olarak tasnif edilen sözcükler/ekler, anlam gösterme işlevleri bakımından değerlendirildiğinde farklı bir mecra oluşturmaktadır. Öncelikle sözcüklerin Türkçede diğer birimler kadar değerli bir işleve sahip olduklarını belirtmek gerekir. Sözün kendi varoluş düzgüsüne/sistemine göre sesten farklı, söz ile birlikte dilde görev alan ama birimsel niteliği bakımından sözü/kelimeyi daha fazla etkin/işlevsel hale getiren ve bunu söz ile ilişkisinin bağlamına uygun biçimde sözü dönüştüren sözcük/ek, Türkçeye özgü temel bir birimdir. Sözcükler/ekler, tek bir sesten oluşabildiği gibi ses öbekleşmesi, sözcük/ek birleşimi ile oluşarak sözün/kelimenin bağlama uygun dönüşümlerini sağlayıp yeni işlevler edinmesine ve gerçekleştirmesine katkıda bulunmaktadır. Bu özelliklerinden dolayı Türkçenin sözcükleri/ekleri, anlam gösterme ve anlatım gerçekleştirme işlevleri bakımından yeniden değerlendirilebilir. Sözcüğün/ekin sözün/kelimenin anlam ve anlatım işlevine etkisi bakımından tanzim ve tasnifi, Türkçenin işlevsel dil bilgisi açısından düzenlenmesi gerekmektedir.

Türkçenin ekleri ile ilgili ortaya konulan araştırmalar, genellikle biçimsel ve kullanılış özellikleriyle değerlendirilmiştir (Korkmaz; 1994). Bilgi, biçim ve işlev özellikleri bakımından eklerin temel dil birimi kelime gibi ve kelimenin alt birimi olarak değerlendirilmeleri gerekmektedir. Ekler, dilin temel işlevini sağlamak için kelime ile birlikte ve kelimenin işlevsel özelliklerine göre görev almaktadır.

Türkçenin isim türü kelime hazinesinin nicelik bakımından yarısından fazlası Türkçeleşmiş kelimelerden oluşmaktadır. Türkçeye diğer dillerden geçmiş olması, isim türü kelimelerin Türkçede kullanılamayacağı ya da Türkçeye zarar vereceği şeklinde düşünülemez. Türkçenin tarihi dönemlerindeki metinleri göz önünde bulundurulduğunda eklerin/sözcüklerin üstlenmiş olduğu rol daha iyi anlaşılabilir. Kelimelerinin tamamının alıntı olduğu bir cümlede ekler aracıllğıyla kelimelerin Türkçeleştikleri ve anlatımın Türkçe olduğu gözlemlenmektedir. Osmanlı Türkçesi dönemi metinlerde Arapça ve Farsçadan geçiş yapan kelimeler ekler aracıllğıyla Türkçenin işletim sistemine göre dönüşüp anlaşmayı sağlamışlardır. Bugün benzer uygulama bilim ve teknoloji ile ilgili kelimelerin kullanımlarında da gözlemlenmektedir.

Türkçede eklerin hepsi (yapım ve çekim ekleri) anlamın gösteriminde belirleyici görev almaktadır. "baba+n" kelimesindeki $+n$ eki, "senin baban olduğunu" anlam açısından göstermektedir. "okul+lar" kelimesinde +lAr eki, "okulun tek olmadığ1 ve çok olduğu" anlamını göstermektedir. "gel-ince" kelimesinde -IncA eki, "gelme aktivitesinin gerçekleştiğini ve sonrasında bir aktivite daha yapılacağı" anlamını göstermektedir. "aile+ce" kelimesinde +cA eki "aile fertlerinin birlikte olduğu" anlamını göstermektedir. "koş-acak-tı-k" kelimesinde -AcAk-DI-k ekleri, "biz koşu yapmayı düşünüp planladık, niyetlendik ama gerçekleştiremedik yani koşamadık" 
anlamını göstermektedir. "kır- ile kır-1l-“" kelimeleri arasında -Il eki sözün anlam değil, anlamlar göstermesini sağlamaktadır. "kır-; maddesi sert olan bir şeyi parçalamak, kırıl- ise üzülmek, alınmak" anlamlarını göstermektedir. Örneklerde de görüldüğü gibi her ek/sözcük anlam göstermektedir.

Çalışmanın bundan sonrasında "söz" yerine kelime ve "sözcük" yerine ek terimleri tercih edilecektir. Yapılan açıklamalar ve gösterilen örnekler, Türkçede "ses, kelime ve ek"in anlam gösterme açısından birimsel özelliklerini açıklamıştır. Türkçede "ses ve ek" söz/kelimedir. Dil bilgisi, ses ve eki "kelime" olarak konumlandırıp incelediğinde diğer birimleşme sorunlarını da çözmüş olacaktır. Çünkü bu dil birimlerinin işlevsel özellikleri dilin kompozisyonu açısından kelime olarak değerlendirmeyi zorunlu kılmaktadır. Bu da dil birimleri arasındaki düzeni, dilin kendi issleyiş sistemine göre düzenleme imkanı sunmaktadır.

Anlam ilgi ve ilişki kurduğu diğer anlamlarla varlıkları "kavram" olarak düzenlemektedir. Kavram, diğer kavramlarla var olabilen ve dilin evrenine söz ile geçiş yapıp "kelime" ile işlevsel kimlik kazanan insan-varlık ilişkisinin insan lehine ya da insan için "kendileşme/kendini gerçekleştirme" aracı olarak açıklanabilir. Kavram üretmek, insanın "olana ve gerekene" göre kendisini konumlandırma ve koruma çabası olarak da düşünülebilir. İnsan diğer canlılara göre fizyolojik ve biyolojik olarak geride olmasina rağmen anlama, kavrama ve anlatma becerileri sayesinde daha üst bir noktadadır. Kavramlar, anlamın tanzimi, tasnifi, tasavvuru ve tasarrufu bakımından dilin işaretleme özelliğine ihtiyaç duyarlar. İşaretleme/etiketleme/iz/im/damga dilde “isim" ile yapılır. Dil, zihnin bağ kurabildiği her şeyi, "şey"den bağımsız olarak işaretler, yani isimlendirir. Bundan dolayı dildeki bütün kelimeler isim olarak var olabilirler. Kelimenin kendini isim/damga/işaret/im olarak konumlandırması bir zorunluluktur. Dilin doğası gereği yapmış olduğu isimlendirme, dil bilgisinde farklı bir düzgüye evrilir. Bu dilden değil, zihnin dili anlama ve anlatma ihtiyacından kaynaklanmaktadır.

Türkçenin isim tasavvuru ve tasarrufu, kelime algısı ve işletiminden farklıdır. Kelimelerin isim, fiil, sıfat, zarf, bağlaç şeklinde tasnifi teorik/bilgi olarak mümkün olabilir, ancak Türkçenin işletim sisteminde kelimenin teorik işlevleri değil, dilin kendini gerçekleştirme (kimliği) özellikleri göz önünde bulundurulmalıdır. Kelimeler, her zaman ve koşulda temsil/vekalet/işaret ettikleri kavramların özelliklerine göre adlandırma yapmamaktadır. Anlamın gösterimi, anlatımın gerçekleşmesi ile anlamın adlandırılması bir biriyle ilgi ve ilişki noktaları olmasına rağmen aynı düzgüde (sistem) değerlendirilemez. Kelimenin dildeki birim özellikleri ile ismin dildeki aynı ölçütlere göre değerlendirilemez. Kelimenin isim olmak gibi bir zorunluluğunun olması, isimlerin de kelimenin birimsel özelliklerine göre davranacağı anlamına gelmez. "Gazi Mustafa Kemal Paşa" kelime değildir ama bir isimdir. "A benim kel oğlum, keleş oğlum” ifadesinde geçen "A” kelimedir ama /a/ sesinin ismi değidlir. "Çocukların solunum yollarında görülen enfeksiyonların gribe sebep olması" öbeği anlam göstermektedir ama bu anlamı işaretleyen bir isim bulunmamaktadır. Bundan dolayı, kelimelerin bilgisi ile isimlerin bilgisi ayrışmaktadır. Türkçede kelime işletimi isim işletim sistemine mecburdur fakat isim işletim sistemi isimlerin mahiyetine göre bir bilgi alanı oluşturmaktadır. "çizgisi” kelimesi isimdir, iyelik üçüncü kişiye işaret eder, fakat sadece "iki nokta arasındaki çizgiyi” göstermemektedir. "onun karalılığı, ilkeleri, davranışlarındaki kompozisyonu” da göstermektedir.

Kelime ile isim arasındaki ayrımlardan biri de isimlerin işaretledikleri varlıklarla doğrudan ilişki kurmalarıdır. Kelimeler kavramların dilselleşmesini sağlarken isimler onları işaretlerler. Dil sistemi bu ayrımı yapmak zorundadır, çünkü bazı kelimelerin isim, fiil, bağlaç, ünlem vb. şeklinde ayrışması ve kendileriyle ilgili bilgi alanı oluşturmaları, dilin işleyişini kolaylaştırdığı gibi dilin kimlik kazanmasını da sağlar. Dil, kendine ait bir adlandırma düzeni oluşturur. Türkçe dil bilgisi kitaplarında belirtilen isimden ya da fiilden isim türetimi, isim ihtiyacından mı yoksa anlam gösterme ihtiyacından mı yapılmaktadır? Kelimeler ile ilgili tanzim ve tasnif çalışmalarında bu özelliklerin bulundurulması gerekir.

Kelimenin kelime ile birleşimi, yeni kelimelerin ortaya çıkmasını sağlar. Birleşik kelimeler olarak adlandırılan bu tür kelimeler de anlam gösterme ve anlatım gerçekleştirme işlevlerini karşılarlar. Birleşik kelimeler en az iki kelimenin tek kelime oluşturacak şekilde birleşmesiyle oluşur. 
Birleşik kelime oluşumuna katılan kelimeler farklı niteliklerde olabilir. Dil bilgisi kitapları bu kelimeleri biçim özelliklerine göre tasnif ederek değerlendirir. Kelimelerin birleşimleri için Türkçe dil bilgisinde belli bir ölçüt yoktur. Bazı kelimeler birleşimde ses değişimlerine uğrar, bazıları tür değişimine bazıları da gösterdiği anlamı değiştirip yeni bir tür ve anlam gösterimiyle kullanılmaya devam ederler. Birleşik isim, birleşik fiil, birleşik edat ve birleşik ek olarak adlandırılan bu kelimelerin birleşme sebepleri de anlam gösterme ve anlatım gerçekleştirme işlevi içindir. Kelime birleşmeleri, dilin kelime üretim kaynaklarından birini oluşturur.

Kelime oluşumu ve anlam gösterme işlevi bakımından birden fazla kelime kullanılan öbeklerin ifade ve temsil gücünün artırılması için öbeği oluşturan kelimelerin ilk sesleri ya da öbekteki kelimelerin niteliklerine uygun tercihlerle kısaltma kelimeler oluşturulmakta ve dilin anlaşmayı sağlama işlevinde kullanılmaktadır. Dilin doğal sisteminin ürettiği kelimelere göre daha sınırlı ve dar bağlamda kullanılan bu kısaltma kelimeler, Türkçenin kelime bilgisine uyumlulukları oranında yaygınlık ve bağlam oluşturmaktadır. Özellikle isim ve özel isim (marka) olarak kullanılan kısaltma kelimeler kurum, kuruluş ve ürün isimleri olarak tercih edilmektedir. Kısaltma kelimelerin doğrudan anlam gösterme ve anlatım gerçekleştirme ile ilişkisi yoktur, fakat ses düzeni bakımından dilin sistemine uyumluluğu etki bağlamı kazandırabilir.

Kelimeler, dil bilgisi kitaplarında kök, gövde, türemiş; isim, fiil, edat ve isim, fiil, zarf, sıfat, zamir, bağlaç, ilgeç, ünlem şeklinde tasnif edilmektedir. Bu sınıflandırmanın dışında kelimeler anlam gösterme ve anlatım gerçekleştirme işlevleri bakımından da sınıflandırılabilir. Anlam gösterme işlevi bakımından kelimeler, "kavramsal (ilgi), bağlamsal (ilişki) ve bilgisel (bilgi)" niteliklerine göre de sinıflandırılabilir. Kelimelerle ilgi ve ilişkisinden dolayı ekler de bu üç temel başlı̆ga göre tasnif edilebilir. Mevcut dil bilgisi kitaplarına göre yapım ekleriyle türetilmiş olan olan kelimeler, son durumlarına göre de sınıflandırılabilir. Bir kelimenin ek vasıtasıyla yeni bir kelime olması sadece isim, fiil ve edat ve bunların cümledeki görevleri üzerinden tartısılması, Türkçe dil bilgisindeki ihtilafların kaynağı olduğu gibi Türkçenin öğretim süreçlerinde de sorun oluşturmaktadır.

Dil ve yazı ilişkisi, dil hakkındaki bilgi ve tutumların değişimine sebep olmuştur. Yazı, dili korunaklı hale getirirken diğer taraftan sadece duyulana/işitilene değil, görülene/okunana göre değerlendirme imkanı oluşturmuştur. Yazı dili, artık sadece okunan değil uyaran, fark ettiren, gösteren özellikleriyle de dil hakkındaki değerlendirmelerin/fikirlerin kapsamını genişletmiştir. Yazı, dile noktalama ve imla kurallarını bir bilgi ve uygulama alanı olarak zorunlu hale getirirken kelimelerin de yazım düzenlemesini gerekli kılmıştır. Türkçe yazım kılavuzunda "ayrı yazılan birleşik kelimeler" şeklinde bir kural vardır. Bu çalışmanın ortaya koyduğu yaklaşıma göre kelimelerin imlası ile ilgili bu tür mantık uyuşmazlıklarına son verilmelidir. En az iki kelimenin katılımıyla oluşan ve bitişmeyen bu dil birimleri öbekleşmektedir. Seslerin öbekleşmesi kelimeyi nasıl oluşturuyorsa kelimelerin öbekleşmesi de kelime işlevli ama kelimeden farklı yapıda birimler oluşturmaktadır. En az iki kelimenin katılımıyla oluşturulan bu birimler, sadece "öbek" olarak adlandırılabilir. "Ayrı yazılan birleşik kelimeler" ismi/terimi/kelimesi anlam ve mantık olarak sorun oluşturmaktadır. Dilin doğal sistemi/düzeni anlam gösterimi ve anlatım gerçekleştiriminde bulanık alanlara izin vermemektedir. Çünkü var oluş sebebi "anlaşmayı sağlamak" olan dil, açıklık ve anlaş1lırlık ilkesine göre inşa olunmaktadır. Dilin doğasına aykırı kullanımların dil bilgisi ile ilgili konularda olması, anlaşmazlık alanları üretmekten başka bir sonuç doğurmamaktadır. Kelimenin bilgisinin açı ve anlaşılırlığı, odağını kelimenin oluşturduğu diğer dil birimlerinin de anlaş1lırllğını sağlar.

Türkçenin kelime üretim yolları bellidir fakat kelime teorisi/bilgisi yeterince işlenmemiştir. Diller kendi sistemlerinin kelime üretim yollarını etkin bir şekilde kullanamadıklarında diğer dillerden kelime geçişlerine kapıyı aralamış olurlar. Bilişim ağlarının yaygınlığı ve iletişim araçlarının hızı karşısında kelime geçişlerinin kontrol edilmesi pek kolay olamamaktadır. Bu durumda ya geçiş yapan kelimeler olduğu gibi dilin evrenine katılacak ve söyleyişten yazıma kadar pek çok sorunlu alan oluşturacak ya da kelimeler dilin sistemine bilinçli şekilde dönüştürülerek dahil edilebilecektir. Bu konuda Türkçede kelimelere karşıllk üretme yöntemi kullanılmaktadır, ancak bu yöntem yeterince etkili olamamaktadır. "buzdolab1 ve bilgisayar" kelimeleri bu yöntemle üretilen kelimelerden sadece iki tanesidir. Bu kelimeler anlam gösterme işlevleri bakımından yanlış 
üretilmiştir, çünkü bilgisayar, bilgi sayımı işlemi yapmaz; buzdolabı da buz yapınca arızalanmış demektir. Faraza, buzdolabi için "soğutucu", klima için "serinletici", vantilatör için de "üfüreç" gibi karşlıklar, bu varlıkların gelişim ve değişimlerine göre belli bir mantık zinciriyle devam edebilirdi. "deep freeze" için "derin dondurucu" karşıllğı kullanılmaktadır. Bu varllğın üstten kapaklı ticari amaçlar için kullanılanı kısmen derin dondurucu olsa da ev için tasarlanmış olanlar önden kapaklı ve bir derinliğe sahip değildirler. Kelimelere sadece karşıllk bulmaktan ziyade kavramsal niteliğine uygun isimlendirmeler yapılabileceğiyle ilgili kuramsal çerçeve oluşturulabilir. Bunun mümkün olmadığı durumlarda da kelimenin söyleyiş ve yazımı, Türkçenin ses ve harf düzenine uygun şekilde dönüştürülebilir. Bu konuda etkin olan alanlar çeviribilim, yabancı dil eğitimi veren bölümler, iletişim araçları ve bilim dünyası gibi yabancı dillere maruz kalan çalışma alanları, Türkçenin kelime bilgisini ve dil sistemini etkin bir şekilde kullanabilirler.

Derlem tabanlı sözlük çalışmaları, kelimelerin takibi açısından oldukça fazla imkanlar sunmaktadır. Özellikle kelimenin kullanım sıklığı, bağlamı ve anlamı ile ilgili gelişimler yakından gözlemlenebilmektedir. Bu çalışmanın doğrudan kapsamında olmamakla birlikte Türkçenin kelime varlığındaki alıntı kelimelerindeki artış meselesi, dil bilgisi öğretiminin kapsamında değerlendirilebilir. Mesela, "at binmek ve ata binmek" örneğindeki durumun bir doğru yanlış meselesi mi yoksa bir gelişme ya da değişme mi olduğu, dil bilgisi sisteminde açıklanabilmelidir.

Türkçe için en etkili ve yaygın kelime üretim sistemi eklileşmedir. Eklerin bazıları kelimelerin dönüşümleriyle bazıları eklerin birleşimleriyle bazıları da seslerin dönüştürücü işlev üstlenmesiyle oluşmuştur. Kelime üretim işlevli eklerin (yapım ekleri) önemli bir kısmı, Türkçenin ilk yazı belgelerinden bu yana süreklilik gösterirler. Ekler, işlevsel dil birimleridir ve bundan dolay1 birden fazla işlev gerçekleştirebilirler. Bazı ekler kelime üretiminde ismi fiile, fiili isme, ismi isme ve fiili file dönüştürürler (Gedizli; 2012). Bu durum Türkçede olağan bir işleyiştir, çünkü Türkçede "sesteş, kökteş ve anlamdaş" kelimeler bulunmaktadır. Eklileşme sistemiyle işleyen Türkçenin eklerinin birden çok işlevinin olması da olağandır. Dolayısıyla Türkçenin ekleri, biçim özelliklerinden ziyade bitiştiği kelimedeki anlam gösterme ve anlatım gerçekleştirme işlevine göre de siniflandirılabilir.

\section{3. Öbek ile Anlam Gösterme}

Kelimelerin katılımıyla oluşturulan ve kelimenin işlevini sağlayan temel dil birimlerinden diğeri de öbektir. Öbek en az iki kelimenin katılımıyla oluşan, ses ve kelimenin yerine getirdiği görevleri kendi niteliklerine göre yerine getiren temel dil birimidir. Türkçede öbekler, tamlama, kelime grubu, söz öbeği gibi başlıklar ile gösterilmektedir. Dilin temel işlevi olan "anlaşmayı sağlama" özelliğine göre anlam gösterme ve anlatım gerçekleştirme aracı olarak kullanılan öbekler, ses ve kelime ile eşdeğer niteliktedir. Öbeklerin yapı ve muhteva özellikleri, ses ve kelimeden farklı fakat işlevsel özellikleri ise benzer niteliktedir.

Türkçede öbekler, yaygın bir kullanıma sahiptir ve isim, fiil, edat gibi doğal dil birimlerinin de gösterimlerini sağlarlar. Öbekler, yardımcı unsur kullanmadan oluşabilir; "dönme dolap, altın adam, cam kase vb.". En az iki kelimenin katılımı bunun için yeterlidir. Diğer taraftan eklileşme, bağlaç,

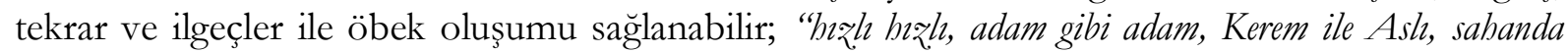
yumurta, diş kapınm mandal vb.”. Öbeğe katılan kelimelerin arasında ilgi ve ilişki zorunlu değildir, ancak öbeğin bir bağlam oluşturması gerekir; "çat kapı, ayna mayna, paldır küldür vb.". Türkçe dil bilgisi kitapları öbekleri, tamlama, ikileme, deyim, atasözü, kelime grubu başlıklarında incelemektedir.

Öbekler, cümle bilgisi/söz dizimi alanının konusu olarak değerlendirildiğinden dolay1 sadece cümle ile ilgili bir birimmiş gibi değerlendirilmektedir. Oysa öbek birimler, kelimenin/sözün zorunlu isimleşme özelliğinden farklı olarak anlamın belirginleşmesine daha çok katkı sunan dil birimleridir. İsim olmalarının ötesinde ismin özelliklerini de göstererek daha anlaşılır duruma getirmektedir. Kelimeler gibi anlam göstermek ve anlatım gerçekleştirmek, öbeklerin temel işlevlerindendir. Öbeklerin birimsel bilgileri ile ilgili çalışmalar, Türkçenin temel birimlerinden birisi olduğunu ve bununla birlikte kendilerine özgü bir bilgi alanı oluşturduklarını göstermektedir 
Gedizli, M. (2021). Türkçenin anlam gösterme ve anlatım gerçekleştirme düzeni. Journal of Human Sciences, 18(3), 400-430. doi:10.14687/jhs.v18i3.6195

(Gökday1; 2018). Öbeklerin kelime üstü ya da kelime alt birimi olup olmadıkları ile ilgili değerlendirmeler, kapsamlı incelemeler sonucunda yapılabilir.

Türkçede kelimeleşen seslerin öbekleşmesinden bahsedilebilir. Öbekleşen ses kelimeler, dil

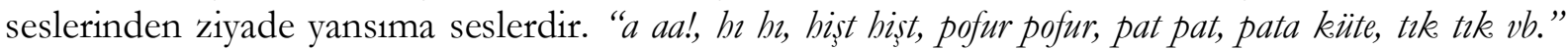
örneklerde görüldüğü gibi hem ses yansımalı kelimelerin ikileme olarak adlandırılan öbekleri oluşturmaktadırlar. Bu öbeklerin gösterdikleri anlamlar, harekete ve hareketin niteliğini belirtmektedirler. Anlatımın niteliğini artırmak ve anlamı bağlamına uygun şekilde ifade etmek için daha yaygın kullanılsalar da dilin anlaşma sağlama işlevine diğer temel birimler gibi katkıda bulunurlar.

En az iki kelimenin katılımı ile oluşturulan öbekler, eklerin de öbekleşmelerini sağlamaktadır. "daldan dala, günden güne, uqaktan u₹ăga vb." öbeklerde +DAn +A şeklinde ek öbekleşmesinin sistemleştiği söylenebilir. "gelir gelmez, görür görmez, kalkar kalkmaz, vb." öbeklerde $\mathrm{Ir} /-\mathrm{Ur}-\mathrm{mAz}$ ek öbekleșmesidir. Bu örneklerden hareketle ek öbekleșmeleri ile ilgili ayrıntılar ikileme ile ilgili çalışmalarda gözlemlenebilir. Bağlaç işlevli kelimelerde de öbekleşmelerin olduğu görülür. "ve yahut; ev ve okul yahut iş fark etmez, ya ya da; ya sen gel ya da kardeşin gelsin, hem hem de; hem hastasin hem de çalısıyorsun, dahası da; dahası bahklar da, ne ne de; ne gelen ne de bekleyen vb." örneklerinde görüldüğü gibi bağlaç işlevli kelimeler de öbekleşmektedir. Bir ek ile kelime/ilgeç de Türkçede öbek kurabilir. " $+A$ kadar; aksama kadar, $+D A$ n dolayl; yağmurdan dolayl, $+\operatorname{In} /+n I n$ gibi; senin gibi vb." örnekler öbeklerin kuruluşunu sağlarken ek-kelime öbekleşmesi oluştururlar. Birleşik filller de bir öbek örneği oluştururlar. "kontrol et-, yardım et-, destek ol-, namaz kul-, fark et- vb." yardımc1 fiiller de öbeklessme yoluyla oluşmuşlardır. Temel anlatım birimi olarak cümle de öbekleşme yoluyla oluşmaktadır. Cümle işlev bakımından anlatım gerçekleştirici dil birimi olmakla birlikte anlam da gösterme işlevi yerine getirir. Söylenmiş her ifade bir anlam göstericidir.

Türkçede öbekler ile ilgili kapsamlı incelemeler yapılmışır ve dil bilgisi kitaplarındaki değerlendirmeler de göz önünde bulundurularak öbekler hakkında ortaya konulan düzenlemeler, bu çalışmadaki yaklaşımın da dayanağını oluşturmuştur. Kalıp sözler de öbeklerden oluşmaktadır (Gökdayı; 2011). Genel olarak öbek, tüm dillerde kullanılan ve evrensel dil bilgisinde de kabul edilen bir dil birimidir. $\mathrm{Bu}$ çalışmanın öbeklerle ilgili ortaya koyduğu yaklaşım, dilin temel işlevini sağlamalarında kelime ile aynı nitelikte olmalarıdır.

Öbekler işletim ekleri ile daha çok kullanılırlar. Anlam gösterme işlevi olan yapım ekleri öbeğe katılan kelimelerde bulunur, ancak öbek oluşumunda belirleyici görev almazlar. "antikacı çırağ " öbeğinde +CI yapım ekinin öbekle bir ilişkisi yoktur ama "çırak $(\breve{\mathrm{g}})+1$ " kelimesindeki $+\mathrm{I}$ işletim eki öbeğin oluşumuna katkı sunmaktadır. "antikacı çrak ile antikacı çră̆ı" öbekleri arasında anlam gösterimi bakımından farklılık vardır. İkinci sıradaki "antikacı çırağı" öbeğindeki +I işletim eki anlam gösterimini yönetmektedir. Bundan dolay1, kelimelerin morfolojik bilgisi ile öbeklerinki kendilerine özgü bir mecra oluşturmaktadır.

Öbeklerin anlam gösterme işlevleri kelimelerin anlam gösterme işlevlerine göre daha belirleyici ve açıllayıcıdır. "Masa kurulur, acıkanlar çağrnlır" ile "Tabta masa kurulur, bir dilim ekemeğe acıkanlar çağrllır" cümlesi ögeleri bakımından eş değerdir, ancak ikinci cümledeki öbekler anlamı daha açık duruma getirirler. Kelimeler ile öbekler arasındaki önemli ayrımlardan biri de; kelimeler gösterdikleri anlamı isimleri ile birlikte belirtirken öbekler ise anlamı daha açı göstermeye çalışırlar.

Öbekler, en az iki kelimenin katılımılla kurulan temel dil birimleri olup her iki ögesi de öbeklerden oluşan tek öbek olarak bir anlam gösterebilirler. "Almancı Mustafa'nın büyülk kıə̨"

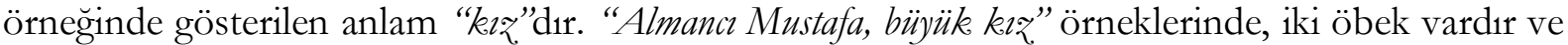
bu öbekler bir önceki öbeği oluşturmaktadır. Öbeğin oluşumunu +nIn +I ek öbekleşmesi sağlamıştır. Yukarıda da belirtildiği gibi ekler/sözcükler kelimenin anlam göstermesinde belirleyici olmaktadır. Öbeklerin katılımıyla oluşturulan öbeklerde anlamın görünümüyle ilgili belirsizlikleri ortadan kaldırmak için belirginleştirici ek, kelime ya da öbekler getirilebilir. "Sażdan Sözenin sanatç konuklar" örneğinde "Sazdan Söze, sanatç konuklar" şeklinde iki ayrı öbek, +nIn +I ek öbekleşmesi ile tek öbek haline gelmiştir. "saz+dan söz+e" öbeği ise +DAn +A ek öbeği ile oluşturulmuştur. Türkçe dil bilgisinin "hal/durum" eki olarak adlandırdığı ve çekim eki sınıfina dahil ettiği ek 
grubunun öbeklerin kuruluşunda üstlendikleri görevlerden dolayı "yapıc1/kurucu/oluşturucu" işlevleri de gözlemlenmektedir. Bu özellikleri, hal eklerini kelime üretimindeki "yapım/türetim ekleri” ile ortak bir işlevde buluşturmaktadır. Yapım ekleri kelime üretiminde, hal ekleri ise öbek oluşumunda "anlam gösterme" işlevi görmektedir.

Örnekler ve açıklamalar, öbekleri sadece cümlenin konusu olarak değil, ses ve kelime gibi dilin temel birimi olarak kabul etmek gerektiğini göstermektedir. Türkçede öbekler, kelimeler gibi çok amaçlı olarak kullanılabilmektedir. Öbeklerin oluşum ve işletimi ise kelimelerden farklı bir düzenek oluşturmaktadır. Birimsel niteliğinin de kendine ait bilgi alanı oluşturmasından kaynaklanmaktadır. Türkçenin dil bilgisi kurgusu, temel birimler ve onların dilin varoluşuna sağladıkları katkıya göre düzenlenmesi, Türkçe dil bilgisini işlevsel hale getirecektir.

Bu bölümünde ortaya konulan tespitlere göre Türkçenin anlam gösterme işlevini karşılayan birimleri şunlardır: a) Ses, b) Söz/Kelime ile birlikte ek, c) Öbek. Bu birimler, Türkçenin anlaşmayı sağlama işlevinde anlam göstericidirler. Ortak özellikleri ise var oluşları bakımından sesten öbeğe kadar aynı işlev için ve aynı yöntemle kurulmuş olmalarıdır.

\section{Türkçenin Anlatım Gerçekleştirme Düzeni}

Dilin kökeni ile ilgili çok farklı teoriler vardır. Bu konudaki çalışmalar felsefe, antropoloji, sosyoloji, pedagoji, psikoloji ve arkeolojinin ilgisindedir. Dil bilimi ve dil bilgisi bu konudaki tartışmalara mesafeli durmaktadır. Dil biliminin çalışma alanı dilin hali hazırdaki verileri (metinler) üzerinden ilerlediği için dil bilgisi kitapları ve dil araştırmaları kaynakçasında dilin kökeni ya da insanda dil gelişimi ile ilgili bilgilere yer verilmez. Dil bilgisine göre kural dişına çıkan dil kullanımının "yanlış" olarak işaretlenmesi tek seçenek olarak görülmüş ve kural dışı dil kullanımları ya istisna olarak işaretlenmiş ya da mevcut kuralın bilgisine göre açıklama yapılmaya çalışılmıştır. "At bindike ile ata bindik vb." cümleleri arasındaki fark, doğru ve yanlışlık ölçütüne göre değil, "anlaşmayı sağlayıp sağlamadığına" göre değerlendirilebilir.

İnsanın dil ile ilişkisinde "anlam ve anlatım” açısından öncelik sonralık ilişkisi var mıdır? Bebeklerin ağlamasının dil bilgisi için bir değeri var mıdır? Bebekler, önce anlayıp sonra mı anlatır yoksa önce anlatıp anladıkça anlatım biçimlerini mi değiştirir? Bebeklerin ağlaması ile eniklerin (hayvan yavrusu/yavru hayvan) çıardıkları sesler arasında bir ilgi kurulabilir mi? Psikoloji ve pedagojinin ortaya koyduğu çalışmalar, bebeklerin dil ile ilişkisinin kaynağında "ağlama, agulama, bıdılama" gibi evrelerin olduğunu ve bu süreçlerin kişiyi dil kullanmaya hazırladığı şeklinde değerlendirilir (Piaget; 2007, Solso vd.; 2007, Topbaş; 2010). Bununla birlikte dil gelişimi ile ilgili ortaya atılan kuramlarda da kişinin dünyaya geldikten sonraki davranışları üzerinden değerlendirmeler yapılır.

Ağlamak nedir? Ağlamak, duygusal bir tepkidir. Bebeklerin doğum sonrası ağlamalarıla ilgili farklı yorumlar yapılmakla birlikte ortak kanaat, akciğerlere giren havanın vermiş olabileceği acı ve doğum esnasında yaşanan zorluktan kaynaklı rahatsızlık karşısında verebileceği tek tepki şeklinde ifade edilmektedir. Bu değerlendirmelere açık internet kaynaklarından ulaşılabilir ve farklı bilim alanlarından araştırmacı ve uzmanların görüşlerini görmek mümkündür.

Ağlamak ile anlatmak arasında doğrudan bir ilişki olmayabilir, ancak ilgi kurulabilir. Yukarıda dil seslerinin dil için üretildikleri ve nefesin dışarıya verilmesi esnasında seslerin oluştuğu belirtilmişti. Diğer taraftan bebeğin doğumdan hemen sonra ağlayarak bir tepki ya da bir uyarıda bulunduğu da araştırmalarda yorumlanmıştır. Ağlamak da akciğerdeki havanın vücuttan dişarıya atılırken çıkarılan sesli davranış olması ve bu eylemle bildirimde bulunulduğu yorumları, insanın dil öncesi evrede dil kullanmaya hazırlık dönemi olarak değerlendirilebilir. Ağlama ve konuşmada sesin üretildiği organların aynı olması ve her iki davranıșta da seslenmenin çağrı işlevi görmesi, bebeklerin ağlaması ile konuşma/anlatım arasında bir ilgi oluşturmaktadır. Her ne kadar bebeğin ağlamasının bir zorunlu davranış olduğu belirtilse de bebeklerin anne karnında beşinci aydan itibaren anlamaya başladığı da açıklanmaktadır (Kahveci; 2019). Dil öncesi dönem olarak adlandırılan 0-9 aylık süreçteki beden ve zihin gelişimlerinin başlangıcı olan doğumdan hemen sonra verilen ilk sesli tepkinin (ağlama) ilerleyen evrelerde etkin kullanımı bebeğin rahatsızlıklarının anlaşılmasını 
Gedizli, M. (2021). Türkçenin anlam gösterme ve anlatım gerçekleştirme düzeni. Journal of Human Sciences, 18(3), 400-430. doi:10.14687/jhs.v18i3.6195

sağlamaktadır. Ağlamanın belli bir dönemde anlatım aracı olarak kullanılması, insanın dil davranışı olarak anlatımı yaşadığı öngörüsünü desteklemektedir. Dil yetisinin en alt seviyesi olarak ya da sıfır noktası olarak işaretlenebilecek olan doğumdan hemen sonraki sesli tepki, dilin temel işlevinin anlatım gerçekleştirme tarafındaki olağan uygulamalarla kesişmektedir. Ünlemler, dilin anlatım gerçekleştirme işlevli birimlerinden biridir ve uyarıcı, dikkat çekici bir seslenme biçimidir. Ağlamanın yeni doğan bebekte canlılık, sağlık veya olağanlık işareti olduğu ve bebeğin doğumdan hemen sonra ağlamamasının olağandışı bir durum olduğu değerlendirilir. Bebek için ne ifade ettiği bilinemeyen ama yetişkinler için ağlamanın bir işaret/mesaj/anlam olarak yorumlanması, anlatımın insanın dünyayla ilişkisinin ilk adımı olabilirliği konusunda düşünülmesi gerektiğini gösterir.

Anlatım da anlam gibi dilden bağımsız var olabilen zihinsel etkinliğin bir parçasıdır. İşitme ve konuşma engelli insanların özel anlatım araçları kullanmaları, dil dışı anlatım araçlarıyla sağlanan haberleşmeler (duman, ateş, 1slık vb.) ve insanın davranışlarıyla muhatapları üzerinde oluşturduğu etki göz önünde bulundurulduğunda, dilin "anlatım gerçekleştirme" işlevinin anlaşılırllğı açığa çıkmaktadır, ancak dilin anlatım gerçekleştirme düzeni, kendi niteliğine göre işlemektedir. Öncelikle anlatım için anlamın zorunlu koşul olduğunu belirtmek gerekir. "Anlaşma"nın bir yanını "anlam" diğer yanını da "anlatım" oluşturur. Bundan dolayı anlam ve anlatım için ses, söz/kelime ve öbekler, amaca uygun şekilde görev üstlenirler.

Bir davranış biçimi olan anlatımın gerçekleşebilmesi için dilin bu amacına uygun birimleri olması gerekir. Dilin doğal birimi olan filler, bir taraftan hareket varlıkların (olay) anlamını gösterirken diğer taraftan da gösterdikleri anlamla uyumlu anlatımlar gerçekleştirirler. Türkçenin fiil varlığı oldukça fazladır (Gedizli; 2019). Fiilleştirme ekleri ve yardımc1 fiil kullanımının dönüştürücü özelliği göz önünde bulundurulduğunda Türkçedeki fiil varlığının niceliği ile ilgili belli bir tespit yapmak da zorlaşmaktadır. Türkçenin doğal birimi olan fiillerinin yanında işlevsel (dil bilgisel) fiillerinden de bahsedilebilir. Anlatım gerçekleştirmek için üretilen bu fiiller, doğal fiillerden işlevsellikleriyle ayrilırlar. Dilin temel birimlerinin üçünde de bu şekilde fiilleşmeler görülebilir.

Anlatım gerçekleştirebilmek için fillin kendine özel bir işleyişi vardır. Fiil ise, hareket sebebi/biri, zaman veya durum/koşul olmak zorundadır. "Fiil, biri/sebebi ve zaman; fiil, biri/sebebi ve durum" şeklinde gösterilebilecek olan anlatım düzeninde, biri/hareket sebebi hep olmak zorunda. Bu, cümle bilgisinde özne olarak belirtilmektedir, ancak bu Arapçanın "faili", İngilizcenin "subject"i değildir. Fiilin sebebi olandır. Türkçede anlatımın gerçekleşmesi, anlatım gerçekleştirici dil biriminin/fiilin sebebi olandır. "Ali on ton yü̈ tasıld ile Kamyon on ton yü̈ taşıdı" arasında özne bakımından fark yoktur. "Ali taşıdı ile Kamyon taşıdı" arasında ise özne farkı vardır. "Kamyon taşıdı" anlatımında özne belirsizdir; taşımayı o mu kamyon mu yaptı, anlaşılmamaktadır. Anlatıma sebep olan unsur anlamdır. Dolayısıyla anlatım gerçekleştirici sözü yönlendiren anlam (anlatım sebebi) fiil için hep olmak zorundadır. Gerçekleşme/hareket/davranış ise ya zaman ya da durum/biçim/tavır olmak zorundadır. Dolayısıyla anlatım gerçekleştirici sözün/fiilin zaman ve tavır/tarz/durum zorunluluğu Türkçenin ürettiği/kurduğu bir zaman ve durumdur.

Anlatımın sebebi, zamanı ve tavrı/tarzı, dünyanın zaman ve tavrından farklıdır. "Yarm

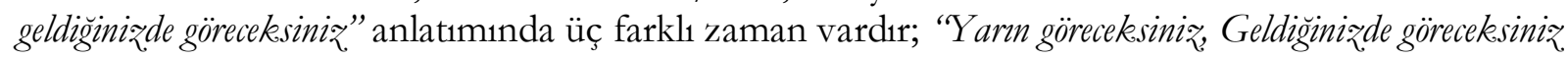
ve Yarn geldiğinizde, göreceksiniæ:” Anlatımın zamanı, anlatıldığ1 andır, yani söylemenin bittiği andır. Anlaşmanın zamanı, anlatanla/konuşanla/yazanla dinleyenin/işitenin/okuyanın buluştuğu/kavuştuğu zamandır. Anlatımın zamanı ise dilin/metnin/anlamın zamanıdır. Anlatım tavr1/tarzı için de benzer bir durum vardır. Mecburiyet, şart ve istek/keyfiyet/niyet/yeltenme/kararsıllı/yetkinlik gibi durumlar, anlam olarak gösterildiği gibi doğal olarak anlatımı da belirlemektedirler. Anlatımın halleri/durumları da dilin anlaşmayı sağlama işlevine göre biçimlenmektedir. Dil bilgisi kitaplarında bu konu bağlamdan yoksun olarak ele alındığından dolayı mesele sadece fiilin çekimlenmesiyle ilgiliymiş gibi değerlendirilmektedir. Fiilin anlatım gerçekleştirici olması, onu anlamdan ayıramaz. Dolayısıyla anlatımın gerçekleşme biçiminde anlamın bağlama katkısı da dikkate alınmak zorundadır. "yapayım, görebilirsin, otur, çıkmalıyı\%, gelemezsiniæ, ağlasan vb." örneklerde görüldüğü gibi anlatımın anlam yönündeki belirsizlikler dikkat çekmektedir. "Ben de yapayım/ Yapayım bari/ Yapayım o vakit; Şimdi/ hemen/ne zaman istersen görebilirsin; 
Gedizli, M. (2021). Türkçenin anlam gösterme ve anlatım gerçekleștirme düzeni. Journal of Human Sciences, 18(3), 400-430. doi:10.14687/jhs.v18i3.6195

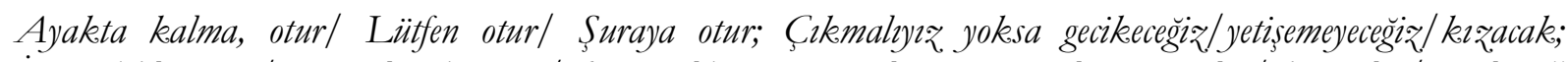

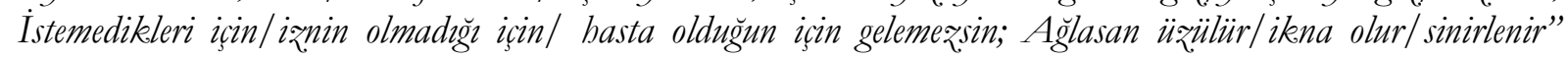
örneklerindeki gibi anlamı belirginleştirici birimler bağlamı göstererek anlatımın niteliğine katkı sunmaktadırlar. Zaten bu anlatım tarzları Türkçede bağlamı zorunlu kılmaktadır.

Türkçenin dil bilgisi kitaplarında fiil işletimi/çekimi başlığında anlatılan bu konu, haber ve dilek şart kipleri şeklinde belirtilmektedir. Anlatımın temel işlevi "bildirim" ya da dilin asıl işlevi iletişim/bildirişim kurmak/sağlamak olarak değerlendirildiğinde, anlatım iki yönlü gerçekleşebilmektedir. Bu da ya bildirim için ya da istek için anlatılabileceği sonucunu çıkarmaktadır. Oysa dilin anlaşma sağlaması temel işlevidir ve bu işlev üzerinden insan, insan olma ayrıcalığını yaşar; anlatır. Bundan dolayı anlatım konusu, anlaşmanın bir tarafı olarak değerlendirilmeli ve anlam ile birlikte incelenmelidir.

Türkçenin anlatım birimleri ses, söz ve öbek temel birimlerine göre biçimlenir/düzenlenir/teşkilatlanır/organize olur. Sesin asıl/doğal işlevi anlatım gerçekleştirmektir. Sesin işitilme ile sesliği/ses olmas1/ses kimliği kesinleşir. Sesin işaretleme/imleme/iz oluşturma işlevi ikincil/kurgusal/dil bilgiseldir. Dil sesi, dil yetisinin bir yanı/parçasıdır. Ses olmadan konuşma/sesli anlatım gerçekleştirilemez. Konuşma engelliler ve bebekler, dil seslerini üretemedikleri için konuşamazlar/sesli anlatım yapamazlar. Söz, kavramın dilin everenine katılmasını/dilsel bir varlık olmasını sağlar. Sözün bir yanı anlam diğer yanı ise anlatımdır. Sözün kavramla ilgili yanı anlam, ses ile ilgili yanı ise anlatımdır. Şu durumda söz, kavram ile ses arasındaki ilişkiyi sağlayan bir varlıktır. Sözün ilişki kurucu özelliği dile/Türkçeye dönüştürücü olarak yansımaktadır. Dildeki dönüşümleri sağlayıcı olması, sözün dili çekip çevirdiğini gösterir. Dil ve söz arasındaki ilginin ilişkisini düşünce düzenler. Dil ve düşünce arasındaki ilişki karşılıklı, dönüşümlü ve zorunludur. Dil, düşüncenin kurgulayıcılığına/düzenleyiciliğine, düşünce de dilin gösterme ve gerçekleştirme işlevine mecburdur. Düşünce dilin temel birimleri aracıllğıyla hem kendini var edebilmekte hem de kendini sunabilmektedir.

["Elif; Abmet'in yakım ama akrabası değil. Elif ile Abmet arasindaki bağ, kendi istekleriyle

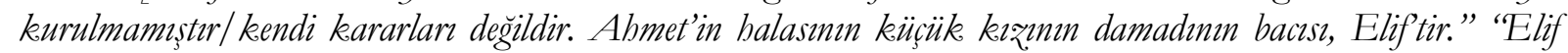
kü̈ü̈, Abmet büyületür; Abmet ibtiyar, Elif genctir; Abmet, Elif'e referans olabilir, Elif, Abmet'e yardimo olabilir; Elif'in ebeveynleri ile Abmet akran olabilir; Abmet'in çocuklar ile Elif akran olabilir; Elif, Ahmet'e saygzll, Ahmet de Elif'e hosgörülü olmahldr vb."' örneği Elifi anlatmaktadır. Görüldügü gibi Elifi bağlamdan bağımsız anlatmak mümkün değil. "Elif' kelimesi bile özel isim/kişi ismi olmasından dolayı bağlam oluşturmaktadır. Bağlam var ise anlatım da vardır. Çünkü anlatımın doğal bağlamını anlam oluşturmaktadır. "elif ve Elif” yazımı/imlası bağlamı göstermektedir ve doğal olarak anlatım gerçekleștirmektedir. Balzac ya da Fuzuli için de aynı aynısı geçerlidir.

"savci, j, v, ögretmen, dişci, iş̧̧, görüntü, kulavuq, rehber, matematik ögretmeni, taksi soförü, uqun yol soförü, hastallk hastasi, kafadan kontak vb." isimleri herkes bilir. "UNESCO, TOBB, IETT, TÜIK, TDK vb." isimleri haber takipçileri bilirler ve muhtemelen açılımlarını bilemeyebilirler. "Akif, Nað̧m, Fikeret, Gökalp, Atsız, Halid Ziya, Yakup Kadri, Tampınar, Kaplan, cinas, kafiye, metafor, üslup, mablas vb." isimleri de Türk edebiyatıyla ilgilenenler bilirler ve lise eğitimi alanlar da bazılarını bilebilirler. Örneklerde gösterilen isimler, anlatım gerçekleştiriciye gerek duymadan kendilerini anlatmaktadırlar.

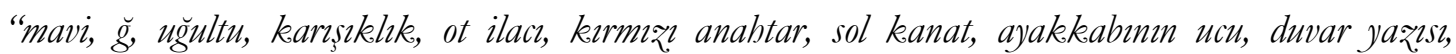
kördügüum vb.” örneklerdeki isimler ise kendilerini yeterince açık edemezler. Bu isimlerin işaretledikleri anlamın anlatılabilmesi için bağlamlarının oluşturulması gerekir. Bağlam; zaman, mekan, ilgi, ilisski, işlev, nitelik, nicelik vb. unsurlarla oluşturulabilir. Bağlama ihtiyaç, anlatım gerçekleştirmek için lazım olur. Bağlam, bazı anlamların/düşünce anlatımının gerçekleşmesi için gereklilik ise diğer bir gereklilik olan "fiil" ile aralarındaki ilişki nedir? Fiil, cümle için zorunlu unsurdur. Bağlamın oluşturduğu anlatımlarda fiile gerek duyulmayabilir.

"Abi - Offf, sabah nöbet!

Kardes - Telefonun...

Abi-Evet, yanmda. 
Gedizli, M. (2021). Türkçenin anlam gösterme ve anlatım gerçekleştirme düzeni. Journal of Human Sciences, 18(3), 400-430. doi:10.14687/jhs.v18i3.6195

Kardes - Rabat ol!

Abi - Teşekkë̈r ederim, iyi ki varsin kardeşim” anlatımı, bağlamla oluşturulmuştur. Aynı bağlam, "Sabah, nöbetim olduğunda hep benden önce uyanan/uyanamama sorunu olmayan sevgili kardeşim telefon edip uyandırı" cümlesi ile de anlatılır. Bağlam içinde cümle olabilir, ancak bağlamı oluşturan unsurlar anlaşmanın gerçekleşmesini sağlamakla yükümlüdürler. Bağlam, cümleden farklı bir anlatım düzeneğine sahiptirler. Bağlam daha çok ifade ya da sözcelerden oluşmaktadır. Bağlam ve cümlede tek amaç anlatımın gerçekleştirilmesidir. Bağlamda anlatım ifade, ima ve işaretleme yoluyla gerçekleştirilir. Cümlede ise anlatım düzenli ve kargaşaya/tartışmaya/ihtilafa izin vermeyecek şekilde gerçekleştirilir. Yukarıdaki bağlam ve cümlenin asıl konusu/anlamı "sabab erken uyanmak/ uyanamamak"tır. Cümlenin yüklemi ile bağlamın kurgusu da bunun üzerine oluşmuştur.

Türkçenin anlatım gerçekleştirici unsurları, dil bilgisi kitaplarında doğrudan belirtilmemiş olsa da morfoloji/şekil/biçim bilgisi ve cümle bilgisi kapsamında gösterilir. İsimler, fiiller, çekim ekleri (isim durum ve fiil) ve son çekim edatları (ilgeçler) Türkçenin doğal bilgisinde anlatım gerçekleştirici birimleridir. Türkçenin Türk düşüncesinin anlatım dili olması, Türkçenin bilgi sisteminin de düşüncenin eleğinden geçirilmesi gerektiğini ve doğal dil bilgisine uyumlu/bağlı/sadık işlevsel dil bilgisinin de üretilmesinin bir ihtiyaç olduğunu göstermektedir. Artık Türkçe, bir ozanın söyleyip toydaki herkesin can kulağıyla dinlediği Türkçe değildir. Herkesin herkesle konuşup anlaştı̆̆1; her konuda fikir açıklayıp tartışan, ikna eden, sorgulayan, ağlatan, güldüren, düşündüren ve dünyanın en uzak köşesindeki insanların bile öğrenmek istediği bir dildir. Dolayısıyla Türkçenin anlatım gerçekleştirme özellikleri dil bilgisi içinde kapsamlı bir şekilde değerlendirilmek zorundadır.

Türkçenin temel birimleri olarak belirtilen ses, kelime ve öbeğin birimleşme niteliğine göre anlatım düzeni oluşturmaktadır. Temel birimlerin anlatım gerçekleştirici özellikleri yukarıdaki örneklerde gösterildi. Türkçe bu temel birimleşme düzenine göre anlatım birimleri üretir. İfade, cümle/söz düzgüsü/söylem ve metin/anlatı/ileti/mesaj/edebiyat Türkçenin anlatım gerçekleştirici temel birimleridir. Bu birimlerin temel özelliği söz/söylenir/anlatım/konuşulur olmalarıdır.

\subsection{Iffade ile Anlatım Gerçekleştirme}

İfade; düzenlenmiş, amaçlı ve işitildiğinde/okunduğunda/sezildiğinde anlaşılırlığ1/açıklı̆̆1 olan anlatım birimidir. İfade birim değeri bakımından cümle ve metinle eşdeğer niteliğe sahiptir. Var oluş gerekçesi, anlatım gerçekleştirmektir. İfade, bir ses ile gerçekleştirilebildiği gibi kelime ve öbek ile de gerçekleştirilebilir. İfade, bağlam kurucu olabildiği gibi bağlamlı birimlerle de oluşturulabilir. İfadenin nicel özelliği sınırlı dil birimi ile etkili/dikkat çekici/nitelikli anlatım gerçekleştirmektir. İfade, cümle işlevli ancak cümleden farklı bir anlatım birimidir. İfade, daha çok konuşma davranışında görev üstlenir. İfadenin anlatım tarzını belirleme ve yönlendirme özelliği vardır. Anlatımın üslup kazanması ve anlaşmanın estetik niteliğinin artırılmasında ifade etkili olur. İfade; sezdirme, hissettirme, etkileme, ima etme, düşündürme, güldürme, uyarma vb. özelliklere sahip anlatım gerçekleştirici anlam gösteren birimleri tercih eder ya da üretir/oluşturur. İfade, yazılı anlatımda noktalama işaretleri ve yazım kurallarını, konuşmada ise sesletim/seslendirme özelliklerini etkin bir şekilde uygular. İfade; aynı ve farklı, benzer ve karşıt özellikleri olan dil birimlerini de etkili uygular. Bir ifade, diğer ifadenin oluşumunda görev alabilir. "Evet demekle olsayd1..."

"Öyle mi?, Ne oldu şimdi?, Anlamadim, Okulun uzun ve çamurlu yollar, Off, Hey!, Eee sonra, Evet, Hay hay, Var, Yok, Keşke, Oysa, On numara, Alo!, Günaydn, Görüsürür, Bekle!, Bas git, Toz, ol!, Gözümün nuru başımm tacı, Gelir gelmę, Bata çıka, /e/nin /i/lesmesi, +lAr, O, Adamm biri, Ot kurutucu ilaçlar, Dünyanm sonu, İ̧inden geçilen süres, Çok beklersin, Elinin körü, Armudun sapı, ü̊ümün çöpü, Daha neler, $O$ bile!, Sence, Bence de, Güya, Günlïk güneşlik bir gün, Bir kaşık suda boğulmak vb." örnekler, birer ifadedir. Görüldüğü gibi temel dil birimlerinin anlatım gerçekleştirici özelliği olan ve ya bağlamı oluşmuş ya da bağlamı kendisi oluşturan unsurları anlatımda kendilerine özgü bir işleyiş ortaya koymaktadır. "kirmıఇ, kirlk sandalye, ama, ancak, gelecek, koșp gelen, günden güne, patates hașlaması, İsmet, ögrenci, ögretmen, ana bilim dal, gece gündür, kösse bucak, kössedeki bakekal, Ayse, mesleğinin beşinci ynlinda, evden okula, gelir ve gider vb.” örnekler ise ifade niteliğine sahip değildir. Gösterdikleri anlam olmasına rağmen 
anlatım gerçekleştirme işlevleri yoktur. "ismet” kelimesi, "İsmet” şeklinde gösterildiği için özel isimdir. "İsmet" bu şekliyle açıklanmaya muhtaçtır. Kendi bağlamı oluşmadığı için de anlatım gerçekleştirememektedir. İnönü/Özel, paşa, hanım/bey, şair/cumhurbaşkanı, anne/baba vb. özellikleri belirgin olmadığından dolayı anlatım birimi niteliğine sahip değildir. "köşe bucak" öbeği, "göz önünde olmayan, kıyı, kenar, saklanmaya/görünmemeye uygun yer" anlamını gösterir. "köşe bucak" nerede, ne zaman, neden, kim sorularına cevap veremez. "köşe bucak saklanmak/kaçmak/aramak" şeklinde gösterildiğinde ifade özelliği kazanır, ancak sadece görünürlüğü özel çaba gerektiren davranışlar işaretlenmezse/belirtilmezse bağlam oluşturamadığ1 için anlatım gerçekleştirici işlev göremez ve dolayısıyla ifade niteliği kazanmaz.

Görüldügü gibi ifade, kendine özgü nitelikleri olan ve anlatım gerçekleştirme işlevi sağlayan anlatım birimidir. Türkçede ifade ile ilgili çalışmalar yeterli seviyeye ulaşmamışır. İfade, ses, kelime ve öbek birimleşmesine göre incelenmesi gerekir. Türkçede ifadelerin bir kısmı "kalıp söz" niteliğindedir. Ancak, anlatımın ifade niteliği kazanabilmesi için kalıplaşması gerekmez. İfade ile anlatım dil yeterliliğinin ileri seviyesinde nitelik kazanır. Temel dil seviyesindeki ifade ile anlatım daha çok argo, sövgü, duygu yansıması ve kalıp söz kullanımı şeklindedir. Reklam, sosyal medya, tiyatro, sinema gibi alanlarda ifade ile anlatım özellikle tercih edilmektedir.

\subsection{Cümle ile Anlatım Gerçekleştirme}

Türkçenin hakkında en fazla inceleme yapılan anlatım birimi cümledir. Cümle, söz dizimi olarak da adlandırılır. Söz dizimi, Fransızca sentaks kelimesinin çevirisidir. Arapçada nahiv olarak adlandırılan cümle/sentaks/sözdizimi, kelime anlamı "yön, usul, metod" demektir. Cümle kelimesi Arapçadan Türkçeye geçmiş ve kelime anlamı "bütün, tüm, hepsi”" demektir. Türkçede ise "duygu ve düşünceleri anlatmaya yarayan sözler" ya da "yargı bildirmek için çekimli bir fiil veya çekimli bir fiille kullanılan kelime dizisi, tümce" şeklinde açıklanmaktadır. Cümlenin kelime dizisi, yarg1 bildirmesi ve bütüncül olması, öne çıkan özellikleridir. Bu özellikler bazı yönlerden anlatım için de geçerlidir. Anlatım; kelime dizisi yerine anlam, yarg1 bildirme yerine anlatım gerçekleştirici ve tümce/bütüncül yerine ise bağlamı yerleştirmektedir. Türkçe dil bilgisinin cümleye yaklaşımı kelime dizilişi, bildirim ve anlam bütünlüğü temeline dayanmaktadır.

Cümle, Türkçenin anlatım gerçekleştirme birimlerinden biridir. Cümle, anlam ile anlatımın bir birimde genel nitelikli anlatım düzeneği kazanmasını sağlayan anlatım birimidir. Cümlenin var olma gerekçesi, anlatım gerçekleştirmektir. Türkçenin doğal düzeninde/sisteminde cümlenin yerinde anlatma/anlatım/konuşma vardır. Cümle dil bilgisel bir birimdir. Düşüncenin aktarım arac1 olarak cümle, düşüncenin ilkelerine göre düzenlenir. Düşünmek, zihin etkinliğine nitelik kazandırma davranışıdır. Düşünce, anlamlar/kavramlar/sözler arası ilgi ve ilişki kurup oldurma/var etme/gerçekleştirme faaliyetidir. Cümlenin de bu amaca uygun bir nitelik kazanması gerekir. Cümle, bağlama gerek duymadan, gerektiğinde dil/söz varlığının bütün imkanlarını tek amaç/anlatım için birleştirip birimleşen anlatım birimidir. Bundan dolayı cümleyi öğrenmek, dili öğrenmenin önemli bir aşaması olarak değerlendirilir. Diğer taraftan cümle, anlatılanın anlaşılıp anlaşılmadığının da kontrol edildiği bir ölçme aracıdır. $\mathrm{Bu}$ da cümlenin başka bir özelliğini gösterir; geçerliliğini/doğruluğunu kendisiyle test eden/ölçen/kontrol eden bir anlatım birimidir.

Cümle, bağlamını kendi içinde oluşturur. Bağlamın oluşumuna katkı sunan temel dil birimleri, cümlede anlama ve anlatıma göre rol üstlenirler. Cümlenin kurucu/anlatım gerçekleştirici ögesi yüklem, fiil olmak zorundadır. Fiil için özne/sebebi/biri zorunluluktur. Fiilleşme/ fiil kimliği kazanma/hareket kendiliğinden olamaz, bundan dolayı dilin fiili birine/sebebine mecburdur. Biri/sebebi anlatım gerçekleşimini/fiili/yüklemi harekete geçiriyorsa zorunlu olarak zaman işleyecek veya amaç olacak. Cümle, biri ve zaman olmadan veya biri ve amaç olmadan asla kurulamaz. Anlatım bu unsurlar olmadan da gerçekleştirilebilir ama cümlenin anlatım birimi olarak özelliği bu unsurlarla anlatımı gerçekleştirmiş olmasıdır. Cümlenin kendini gerçekleştirmiş olan birimi diğer ögeler olmadan da cümle niteliği gösterebilir. Bu şekilde oluşan cümlelerin fiilleri gösterdikleri anlamdan dolayı diğer ögelere ihtiyaç duymazlar. 
Cümlenin diğer ögelerinin cümleye katılımlarına temel öge olan yüklem/fiil/anlatım gerçekleştirici karar verir. Dil, her anlam için anlatım gerçekleştirici/fiil üretmez. Öncelik sahip olduğu fiil varlığ1/söz varlığınındır. Türkçe bu ihtiyacı dönüştürme yöntemiyle gidermektedir. Çalışmanın kapsamını zorlamamak için fiilleştirme yöntemi demek yeterli olur. Bunu kelime eklileşmesi ve öbekleşme (yardımcı fiil: isim-yardımcı fiil; yardım et-, kontrol et-, oruç tut- vb.) yoluyla sağlamaktadır. Cümlenin diğer ögelerinin de gösterdikleri anlama uygun yüklem seçme/tercih etme/belirleme özellikleri vardır. Türkçe cümle bilgisi araştırmalarında, yüklemin kurucu öge olmasından dolayı diğer ögelerin yükleme göre geldikleri tercih edildikleri düşünülür. Oysa cümlenin işlevi, anlam gösterici ve anlatım gerçekleştirici birimler/unsurlar arasında anlamı anlaş1lır niteliğe dönüştürüp uygun/geçerli/doğru bir düzgüyle/düzenekle anlatmaktır/anlatımı gerçekleştirmektir. Dolayısıyla yüklemin cümlenin diğer ögeleriyle ilişkisi anlamın ve anlatımın niteliğine göre oluşur.

"Aylin kosuyor, (Aylin'in kararr)/ Aylin kossandir, (sporsever)

Aylin Nilay' kovalyyor, (Aylin Nilay arasinda iliski)/ Nilay'ı kovalayan Aylindir, (Aylin Nilay'ı etkileyen)

Nilay kaçıyor, (Nilay zorda)/ Kaçan Nilay'drr, (Nilay zorda)

Nilay Aylin'den kaçıyor, (Nilay Aylin ilișkisi)/ Nilay Aylin'den kaçandrr, (Aylin Nilay'ı etkileyen)

Nilay hrąl kosuyor, (Nilay'n kossması nitelikli)/ Nilay hrælı kosusucudur, (Nilay koșu sporcusu/atlet)

Aylin Nilay'dan ağr koşuyor (Aylin Nilay ilişkisi)/ Nilay'dan ăğr kossan Aylin'dir" (Aylin Nilay'ın gerisinde) satır başındaki cümlelerinin yüklemleri benzer nitelikteki anlamları göstermektedir. Satır sonundaki cümlelerde ise ögelerin görevleri değiştirilerek yeniden cümle kurulmuştur. Cümleyi oluşturan ögelerin görev/işlev/rol değişimleri, hem anlamı hem de anlatımı etkilemektedir. Cümle ögelerinin işlev değişimi olmadan diziliş yerleri değiştiğinde anlam ile ilgili bir değişim olmaz, ancak anlatımın biçimi/anlatış değişir. Cümlenin işleyişi açısından bu değişim sorun oluşturmaz.

Cümlenin ögeleri her zaman tek kelimeden oluşmayabilir. "Düssmanlar yaktılar, yıktılar, gittiler" cümlesinde yüklem öbekleşmesi görülür. Aynı cümle "Düşmanlar yakarak yıkıp gittiler" şeklinde de söylenebilir. "Düşmanlar yakıp yıkıp gittiler", "Düşmanlar yaka yıka gittiler" örneklerinde zarf öbekleşmesi görülür. "Arif evi, arabayı ve tarlayı sattı" cümlesinde nesne öbekleşmesi vardır. "Ayşe evden okula, okuldan markete, marketten de kocasına uğrar" cümlesinde dolaylı tümleç/tamlayıcı öbekleşmesi görülür. "Aylin, Mustafa ve anneleri Özlem başarılı sürücüdür" cümlesinde de özne öbekleşmesi görülür. Anlatımı gerçekleştirici unsurlar da anlam gösterici unsurlarla aynı işleyiş özelliğine sahiptir.

Cümle unsurlarının iki yönlü oluşumundan bahsedilebilir; diziliş ve düzenleniş. Söz dizilişi biçimsel yaklaşımı, sözün düzenlenişi ise işlevsel yaklaşımı sergiler. Söz dizimi, kurallara uygunluğu, söz düzeni ise anlaşmanın gerçekleşmesini esas alır. "Var ben gitmek İstanbul" diyen birisi, söz dizimine göre yanlış söylemiştir, söz düzenine göre ise yabancı/az bilen ya da yabancı değilse ima/taklit vb. niyetiyle değerlendirilir. Cümle ögelerinin öbek birimlerden seçilmesi, cümlenin anlatım gerçekleştirme sisteminde bir sorun oluşturmasa bile anlam gösterimi açısından belirsizlik veya kargaşaya neden olabilmektedir. Konuşmada vurgu ve tonlama, yazılı anlatımda ise noktalama ve yazım bilgisi anlatımın parçasıdır.

Cümle ile gerçekleştirilen anlatım; amaçı ve nitelikli anlatımdır. Bağlam cümle ile sınırlandırılmaya çalışılır. Ancak, yine de cümlelerin bağlam öbeklenmesi kaçınılmaz olur. Bağlam öbeklenmesi, aynı bağlamdaki cümlelerin tek bir anlamı anlatması, anlatımın gerçekleşme şeklini değiştirir. Bağlamların öbekleştiği birim, paragraftır. Paragraf da metin ile ilgili bir anlatım birimidir.

\subsection{Metin ile Anlatım Gerçekleştirme}

Metin; anlam ve anlatım bütünlügünün korunduğu, dilin imkan ve işlevlerinin şartlara uygun bağlamlar üretip tek bağlam oluşturacak şekilde sergilendiği anlatı birimidir. İşlevi bakımından metnin ifade ve cümle arasında fark yoktur. Hatta bağlamı tam olan ve gösterdiği anlam ile anlatımını gerçekleştiren temel birimler de metin, cümle ve ifade ile işlevdeştir. Anlatım gerçekleştiren birimlerin ortak özelliği “oluşturulmuş, kurulmuş ve bütünleştirilmiş” olmalarıdır. Oluş, kuruluş ve bütünleşme için zorunlu koşul "bağlam”"dır. Bundan dolayı anlatım gerçekleştirici 
birimler ile ilgili araştırmalarda bağlam ile ilgili ve ilişkili unsurlara özel bir dikkat göstermek gerekmektedir.

Metnin temel özelliği kapsayıcı anlatım birimi olmasıdır. Metin ile ilgili değerlendirmelerde anlam ve anlatım ile ilgili dil birimleri üzerinden yapılan açıklamalar, bilgi sorunlarına neden olmaktadır. "kelime ve cümlelerin bir araya gelerek oluşturdukları anlamlı yazı parçası vb." şeklindeki açıklamaların metnin var oluşunu sağlayan unsur ve gerekçelerle bir ilgisi yoktur. Çünkü metin, anlatım birimidir ve onu bir cümleden ya da kelime birliğinden ayıran özelliği kapsayıcıllı̆̆ıdır. Kapsayıcılı̆̆ın mahiyeti de anlam ve anlatım ile yani, dilin temel işlevi olan anlaşmayı sağlama niteliğiyle belirlenir. "Yazı nokta ile başlar" cümlesi, vecize/özdeyiş ya da atasözü niteliğindedir. Genel olarak "yazı" kelimesinin "yazılı anlatım ya da yazılı metin” öbeklerinin gösterdikleri anlam yaygınlığından dolayı "yazı”"nın bir eylem olarak kalem ucunun kağıt üzerine temasıyla oluşturduğu nokta ile başladığı gerçeği üzerinde çok durulmadığ için noktanın cümle sonunda kullanıldığ1 bilgisinin yaygın kabulü, önce şaşırtıcı olmakta ve biraz ayrıntılı düşünüldüğünde ise yazı ile ilgili bu gerçek fark edilmektedir. "Yazı nokta ile başlar" cümlesini metne dönüştüren anlatım özelliği değil, anlam kapsayıcılığıdır. Metnin tutarlılık ve bağlaşıklık yeterliliklerini de karşılamış olması, cümleye nitelik kazandırmaktadır. Cümle metne dönüşüp bir metin türü olan özdeyiş ya da atasözü niteliği edinmektedir.

Metnin bütünlüğü bağlamla sağlanır. Metnin bağlam birimi, paragraftır. Paragraf, metnin kurucu birimi olmasına rağmen tek bir birim olarak da anlatım gerçekleştirebilir. Paragraf bu özelliği ile kelimeyle benzer nitelikler göstermektedir. Tek bir konuyu ele alan paragraf, konunun anlaşılmasını sağlamaya yönelik açıklamalardan bir bağlam oluşturur. Paragraf, metnin bütünlüğünü sağlamaya katkı sağlayan diğer paragraflarla uyumlu bir akış/izlek/zincir oluşturur. Metnin türüne göre paragraf da türün özelliklerine uyumlu olur. Paragraf hem kendi bütünlüğünü sağlar hem de metnin bütünlüğüne katkıda bulunur. Paragraf, tek cümleyle bağlam oluşturmanın anlatım yönünden sorun oluşturduğu durumlarda, bağlamı cümleler yoluyla oluşturmaya imkan sağlar. Anlam gösteriminde tercih, mümkün olduğunca kelimeler iken anlatım gerçekleştirmede ise anlaş1lırlığ1 sağlamak için daha fazla açıklama yapma gereği oluşur. Bu da metnin temel birimi olan paragraf aracilığıyla sağlanır.

Metnin anlatım gerçekleştirme birimi olarak temel özelliği, bağlamlardan oluşan bir bağlam olmasıdır. Bağlamların öbeklenmesi daha fazla anlam gösterici ve anlatım gerçekleştirici birimin bir araya gelmesi demektir. Dolayısıyla metin, kendi düzenini sağlamak için anlatımın doğasında olan "giriş, gelişme ve sonuç" bölümlerini de belirler. Metnin gösterdiği anlama ve gerçekleştirdiği anlatım biçimine göre oluşan bölümler, metnin niteliğini arttırır. Hem metnin doğası hem de kuralı olarak metnin bölümlere göre oluşturulması, metnin muhatapları için de önemlidir. Metin için diğer bir zorunluluk ise metnin adlandırılmasıdır. Her metin adıyla anılır. Başlık olarak da adlandırılan metnin adı, metnin niteliğine uyumluluk önemlidir. Başlık da metnin gösterdiği anlam ve anlatımla uyumluluğuna göre dilin evreninde kendine yer edinir. Neticede metin, bağlamlar evrenidir ve metnin oluşumuna katkı sağlayan her dil unsuru bağlama anlamlı bir şekilde katılır.

Türkçe, bağlam oluşturucu unsurlar bakımından oldukça geniş imkanları olan bir dildir. Türkçede temel/kök/basit fiiller ve ekler, bağlam oluşturucu özellikleriyle dikkat çeker. Gözlemci/betimsel/tasviri dil bilgisi yaklaşımına göre fiil, ek ve edatlar, bağımlı biçimbirimler olarak değerlendirilir. Bu dil birimlerine işlevleri açısından bakıldığında ise bağımsız biçimbirimlerin bağlama katılabilmeleri için bu birimlere ihtiyaçları bulunmaktadır. Türkçede ek ve fiil kullanmadan bağlam oluşturmak imkansıza yakın bir durumdur. Anlatımın temel unsurları olan ek ve fiillerin Türkçenin bilgi sisteminde özel bir yeri vardır. Türkçenin evrenine katılan dil unsurları genellikle ekler aracillğıyla dönüştürülüp Türkçeleştirilmekte ve fiilerle ya da fiilleștirilerek de Türkçe olarak anlatılmaktadır. Osmanlı Türkçesi metinleri, gerek işlevsel dönüşümleri gerekse de bağlamsal Türkçeleşmeleri gözleme imkanı vermektedir.

Kuramsal bir kimlik olan dilin sürekliliği için işlevsel nitelikleri önemli bir yere sahiptir. Türkçe, tarihinde kuramsal kimliğini destekleyen kavramsal ve kurumsal koşullara sahip olamamasına rağmen var oluşunu bağlamsal nitelikleriyle geliştirerek sürdürmüştür. Türkçe 
konuşan herkesin ninni, tekerleme, mani, ağıt, türkü, deyiş, destan, atasözü vb. metinlerle muhatap olmas1, Türkçenin kuramsal/teorik kimliğini bağlamsal bir çerçeveye oturtmuştur. Bu da Türkçenin metin üretme yetkinliğini artırmıştır.

Türkçede metin, sözün gücü ve dilin etkisine/estetiğine göre nitelik kazanır. Söz ile söyleyenin/anlatıcı/şair/biri değeri metinde ortaya çıkar. Metin bundan dolayı söze ve söyleyene de temsil edilme imkanı sunar. "Nasrettin Hoca, Temel, Atalar, Korkut Ata, şair, adamın biri, fikra, şiir, atasözü, gazete, bilim adamları, hadis, Kur'an vb." isimlere isnat edilerek söylenen sözler metin hükmünde değerlendirilir. Çünkü atıf yapılan isimler, gerek sözleriyle gerekse söyleyişleriyle metin niteliği kazanmışlardır.

\section{Sonuç: Söz/Anlam ise Söylenir/Anlatılır}

Söz olarak dilin evrenine geçiş yapan anlamın söylenmesi, anlatımı gerçekleştirir. Anlatım, dilin kimliğini oluşturan esas unsurdur. Anlamın gösterimi dil için zorunlu koşul değildir, ancak anlatımın gerçekleşebilmesi için anlamın işaretlenmesi/gösterimi zorunlu koşuldur. Anlam gösterimi için dilin ürettiği temel birimler, aslında anlatımın gerçekleştirilebilmesi içindir. Bunun için dil, kendi evrenindeki birimleri anlatıma uygun ya da uyumlu hale dönüştürür.

Anlatım, anlamın yer değiştirmesidir. Anlam, bir zihinden başka bir zihne kendine özgü bir işleyişle geçiş yapabilmek için dil ile ve dil aracılığıyla dile özgü bir düzen/düzgü/sistem oluşturur. Ağı ve kulağın belirleyici olduğu bu düzgüde oluşan aksaklıklar, hem anlamı hem de anlatımı etkilemektedir. Ağız ve kulağın konuşma/söyleme ve işitme/duyma/dinleme faaliyeti, bu iki eylemi, anlatım açısından ayrıcalıklı hale getirmektedir. Artık ses, anlatım ile işaretleyici/gösterici özelliğinden gerçekleştirici/anlatıcı özelliğine dönüştürmektedir.

Dili içi dönüşümler, Türkçenin temel özelliğidir. Dönüşümleri belirleyen anlam ve anlatımın bağlamıdır. Bağlamın kaynağında ise ilgi ve ilişki vardır. Türkçenin fonetik, morfolojik, semantik ve sentaktik değişimleri tesadüf değildir. Değişim geçiren dil birimleri, dönüştükleri birimlerle belli bir ilgi ve ilisskiye sahiptirler. Türkçede anlam gösterme ve anlatım gerçekleştirme, bağlamın yönlendirdiği dönüşümlerle sağlanmaktadır. Bağlam da var oluşunu, insan zihninin varlığa/varlıklara karşı istemli ya da istemsiz tepkisinin ilgi ve ilişkisine göre belirlemektedir. Bağlamın dilin evrenindeki temsilcisi Türkçede "söz"dür. Felsefenin/mantığın "kavram" olarak yerleştirdiği ve dilde "terim" olarak işaretlediği soyut varlığın Türkçenin dünyasında "söz" ve Türkçenin işleyişinde de "kelime/sözcük" olduğu, bu çalışmayla ortaya konulmuştur. Bundan dolayı Türkçe söz ile var olur ve kelime ile işler. Türkçenin var olma ve işleme düzenini söz sağlamaktadır.

Türk dil bilgisi incelemelerinde dil birimlerinin bilgi düzeni söze göre şekillendirilmelidir. Seslerin özelliklerinin tespiti ve bilinen çerçeveye göre tekrar uyarlanmaları, Türkçenin gelişim ve değişim süreçlerinde Türkçenin "anlaşma aracı" özelliğinden ziyade biçimsel işleyişine dikkatleri yoğunlaştırmaktadır. Oysa Türkçe; önce sözü sese katarak sesi, sesi sese katarak kelimeyi ve kelimeyi de kelimeye katarak öbeği var etmekte ve anlaşma aracı olarak Türk aklının yeryüzündeki mührü olmaktadır.

Dil bilgisi/gramer kitaplarının amacı, dilin öğretilmesine kılavuzluk etmektir. Dilin bilgisini dilin işleyiş /var oluş biçimine göre gösterebilen dil bilgisi kaynakları, dil için mihenk taşı olmaktadır. Türkçe, her türlü etkiye karşı kendi duruşunu ispatlamış nadir dünya dillerinden biridir. Türkçenin bilgi düzeni kendine göre olmak zorundadır. Türkçe ile ilgili araştırmaların ortaya koyduğu veri ve bulgular, Türkçe dil bilgisinin yaşanan Türkçeye göre düzenlenmesi gerektiğini göstermektedir.

Bu çalışmanın yöntemi ve yaklaşımı elbette çok yönlü olarak tartışmaya açıktır. Ancak, dilin anlam ve anlatım bilgisi düzenlenmedikçe hangi dilin bilgi şablonu uygulanırsa uygulansın dili kendinden uzaklaştıracaktır. Türkçe dil bilgisi, Türkçenin üretim kanallarını yargılamak yerine açmalı ya da işletmelidir. Türkçenin kelime varlığı ve ifade gücü, dil bilgisi ile ilgili bilgi kanallarının bilgiye dayalı işletilememesinden dolayı, diller arası etkileşim alanında zorlanmaktadır. Türkçe düşünmeyi Türk bilgi sisteminin kurucu temel unsuru dilin eğitimi ile öğretmek mümkündür. 
Gedizli, M. (2021). Türkçenin anlam gösterme ve anlatım gerçekleştirme düzeni. Journal of Human Sciences, 18(3), 400-430. doi:10.14687/jhs.v18i3.6195

Bunun için ileti aracına değil, anlam aracına ihtiyaç vardır. Bu araç bir yanıyla düşünceyi üretirken diğer yanıyla da düşünceyi temsil etmektedir.

İletişim araçlarının yaygınlaşmasıyla Türkçede sanallaştı̆̆ı düşünülen dünya aslında bir sanrı değildir. Yaşanılanlar, insanlık tarihinin yeni bir gerçeğe evrilişidir. Türkçenin okulsuz ve dil bilgisiz tecrübeleri bu evrilişleri, türkünün sözünü ezgisine sarmalayarak izlemesine firsat vermiş olabilir ancak, bu sefer durumun tecelliyatı, tecrübeleri de aratabilir. Çare, Türkçenin anlaşma kanallarının açılmasıdır.

\section{Bu Konuyla İlgili Kaynak Listesi Aşağıdadır:}

Açıkgöz, Halil; Yelten, Muhammet (2005). Kelime Grupları, İstanbul: Doğu Kütüphanesi Yay. Adal1, Oya (2004). Türkiye Türkçesinde Biçimbirimler, 2. Bask1, İstanbul: Papatya Yay.

Akar, Ali (2014). Türk Dili Tarihi, 8. Basım, İstanbul: Ötüken Yay.

Akar, Ali (2019). Düşünen Türkçe, İstanbul: Ötüken Yay.

Aksan, Doğan (1987). Anlambilim ve Türk Anlambilimi, 3. Baskı, Ankara: AÜ Dil ve TarihCoğrafya Fakültesi Yay.

Aksan, Doğan (1999). Anlambilim, Ankara: Engin Yay.

Aksan, Doğan (2003). Her Yönüyle Dil, 2. Baskı, Ankara: TDK Yay.

Altun, Mustafa (2011). Türkçede Kelime Grupları Çözümlemeleri, İstanbul: mtv Yay.

Baskakov, A.N. (2011). Çağdaş Türkçede Kelime Grupları, çev. Oktay Selim Karaca, İstanbul: Kesit Yay.

Baskakov, A.N. (2017). Çağdaş Türkçede Cümle, çev. Oktay Selim Karaca, Ankara: TDK Yay.

Condon, John C. (2000). Kelimelerin Büyülü Dünyası, 3. Baskı, çev. Murat Çiftkaya, İstanbul: İnsan Yay.

Coşkun, M. Volkan (2010). Türkçenin Ses Bilgisi, 2. Bask1, İstanbul: IQ Kültür Sanat Yay.

Çakır, Cemal (2004). "Anlamın Bağlam Açısından İncelenmesi: Kökanlambilim ve Artanlambilim”, Ankara: GÜ, Gazi Eğitim Fakültesi Dergisi, Cilt 24, Say1 3 s.245-255

Çotuksöken, Betül (2000). Felsefi Söylem Nedir?, İstanbul: İnkılap Yay.

Delice, H. İbrahim (2007). Türkçe Sözdizimi, 3. Bask1, İstanbul: Kitabevi Yay.

Demircan, Ömer (1996). Türkçenin Sesdizimi, İstanbul: Der Yay.

Demircan, Ömer (2003). Türk Dilinde Çat1, İstanbul: Papatya Yay.

Demirci, Kerim (2015). Kelime Bilgisi El Kitab1, Ankara: An1 Yay.

Develi, Hayati (2011), Osmanlı Türkçesi Kılavuzu I-II, İstanbul: Kesit Yay.

Dolunay, Salih Kürşad (2012). Türkiye Türkçesinde Zaman, Ankara: Berikan Yay.

Ediskun, Haydar (2004). Türk Dilbilgisi, 9. Basım, İstanbul: Remzi Kitabevi

Eker, Süer (2009). Çağdaş Türk Dili, 5. Baskı, Ankara: Grafiker Yay.

Ergin, Muharrem (2003). Türk Dil Bilgisi, İstanbul: Bayrak Yay.

Erkman-Akerson, Fatma (2008), Dile Genel Bir Bakış, 2. Baskı, İstanbul: Multilingual Yay.

Erkul, Rasih (2007). Cümle Metin Bilgisi, 2. Bask1, Ankara: Anı Yay.

Gabain, A. Von (2007). Eski Türkçenin Grameri, çev. Mehmet Akalın, 5. Baskı, Ankara: TDK Yay.

Gedizli, Mehmet (2019a). Türkçenin Fiiller Sözlüğü, İstanbul: Değişim Yay.

Gedizli, Mehmet (2019b). Türkçede Öbek İsimler Sözlüğü, İstanbul: Değişim Yay.

Gedizli, Mehmet (2020). Türkçenin İsimler Sözlügüü, İstanbul: Değişim Yay.

Gedizli, Mehmet (2012). “Türkçede Tek Şekilli Çok İşlevli Yapım Ekleri”, International Periodical For The Languages, Literature and History of Turkish or Turkic Volume 7/4, Fall2012,p.3351-3369,ANKARA:

https://turkishstudies.net/Makaleler/1532917778_zz096GedizliMehmet_S-33513369.pdf (Erişim Tarihi: 12.06.2021)

Gencan, Tahir N. (2001). Dilbilgisi, Ankara: Ayraç Yay.

Gökdayı, Hürriyet (2011). Türkçede Kalıp Sözler, İstanbul: Kriter Yay.

Gökday1, Hürriyet (2018). Türkçede Öbekler, İstanbul: Kriter Yay. 
Gedizli, M. (2021). Türkçenin anlam gösterme ve anlatım gerçekleştirme düzeni. Journal of Human Sciences, 18(3), 400-430. doi:10.14687/jhs.v18i3.6195

Gülsevin, Gürer (1997). Eski Anadolu Türkçesinde Ekler, Ankara: TDK Yay.

Günay, Doğan (2007). Metin Bilgisi, 3. Bask1, İstanbul: Multilingual Yay.

Günay, Doğan (2007). Sözcükbilime Giriş, İstanbul: Multilingual Yay.

Güz, Nükhet (1992). Sesler ve Kurallar, İstanbul: Der Yay.

Hacieminoğlu, Necmettin (1992). Türk Dilinde Edatlar, Ankara: MEB Yay.

Huber, Emel (2008), Dilbilime Giriş, İstanbul: Multilingual Yay.

İmer, Kamile; Kocaman, Ahmet; Özsoy, A. Sumru (2011). Dilbilim Sözlüğü, 2. Baskı, İstanbul: Boğaziçi Üniversitesi Yay.

Johanson, Lars (2007). Türkçe Dil İlişkilerinde Yapısal Etkenler, çev. Nurettin Demir, Ankara: TDK Yay.

Karahan, Leyla (2005). Türkçede Söz Dizimi, 9. Baskı, Ankara: Akçağ Yay.

Kartallığlu, Yavuz (2011). Klasik Osmanlı Türkçesinde Eklerin Ses Düzeni, Ankara: TDK Yay.

K1lıç, Veysel (2009). Anlambilime Giriş, İstanbu: Papatya Yay.

Korkmaz, Zeynep (1994). Türkçede Eklerin Kullanılış Şekilleri ve Ek Kalıplaşması Olayları, 3. Bask1, Ankara: TDK Yay.

Martinet, Andrev (1998). İşlevsel Genel Dilbilim, çev. Berke Vardar, İstanbul: Multilingual Yay.

Palmer, F. R. (2001). Semantik, çev. Ramazan Ertürk, Ankara: kitabiyat Yay.

Piaget, Jean (2007). Çocukta Dil ve Düşünme, çev. Sabri Esat Siyavuşgil-akt: Yusuf Turan Günaydın, Ankara: Palme Yay.

Russell, Bertrand (2013). Anlam ve Doğruluk Üzerine, çev. Ezgi Ovat, İstanbul: italik Yay.

Sarıca, Bedri (2015). Türkçe Cümle Bilgisi, Ankara: Anı Yay.

Saussure, Ferdinand de (2001). Genel Dilbilim Dersleri, çev. Berke Vardar, İstanbul: Multilingual Yay.

Saussure, Ferdinand de (2014). Genel Dilbilim Yazıları, çev. Savaş Kılıç, İstanbul: İthaki Yay.

Searl, John R. (2005). Bilinç ve Dil, çev. M. Macit-C. Özpilavcı, İstanbul: Litera Yay.

Searl, John R. (2006). Zihin Dil Toplum, çev. Alaattin Tural, İstanbul: Litera Yay.

Solso, Robert L., vd. (2007). Bilişsel Psikoloji, çev. Ayşe Ayçiçeği-Dinn, İstanbul: Kitabevi Yay.

Şencal Sağ, Esma (2014). Mana Oluşumunda İş ve Dış Bağlam Oluşumu: Abdülkahir el-Cürcani ile Saussure Karşılaştırması, Yüksek Lisans Tezi, İstanbul: Fatih Sultan Mehmet Vakıf Üniversitesi.

Şirin, Hatice (2020). Sözcük Hikayeleri, 4. Bask1, İstanbul: Bilge Kültür Sanat Yay.

Tiken, Kamil (2004). Eski Türkiye Türkçesinde Edatlar, Bağlaçlar, Ünlemler ve Zarf Fiiller, Ankara: TDK Yay.

Topbaş, Seyhan (2010). Dil ve Kavram Gelişimi, 4. Bask1, Ankara: Kök Yay.

Türkyılmaz, Fatma (1997). Tasarlama Kiplerinin İşlevleri, Ankara: TDK Yay.

Uzun, Nadir Engin (2000). Anaçizgileriyle Evrensel Dilbilgisi ve Türkçe, İstanbul: Multilingual Yay.

Üçok, Necip (2007). Genel Fonetik, İstanbul: Multilingual Yay.

Ülgen, Gülten (2004). Kavram Geliştirme, 4. Bask1, Ankara: Nobel Yay.

Vardar, Berke (1998). Açılamalı Dilbilim Terimleri Sözlüğü, 2. Baskı, İstanbul: abc Yay.

Zülfikar, Hamza (1995). Türkçede Ses Yansımalı Kelimeler, Ankara: TDK Yay.

\section{Extended English Summary}

Language is a tool that provides communication between people. The feature of the language as a tool can be evaluated as unitization and functionalization of the units, and thus achieving the agreement as a whole. Each language creates a system of reconciliation depending on its own special system. The units of showing meaning and providing expression are also unique as a medium of reconciliation in Turkish. This study attempts to analyze the order of "showing meaning" and "providing expression" in Turkish by considering the basic grammar sources and 
their sub-fields. Turkish grammar topics, which are generally shaped according to the rules of descriptive grammar sources, were discussed in terms of the basic function of language, which is the "reconciliation" feature. Unitization was emphasized in terms of the features of fulfilling the function of meaning and expression, and the identified basic language units were evaluated according to their functions in the general functioning of Turkish.

Language is a phenomenon that is analyzed and sought by different scientific disciplines. Each field of science evaluates language according to its own approach. Findings about language also encourage us to re-examine the knowledge about language. In this regard, the study took into account the findings of other scientific fields, starting the relationship of humans with language at birth along with the development of language in an individual's world. Besides the approaches of grammar that consider language as a form or shape, the transformations of language units are paid great attention in Turkish when the language is evaluated functionally. Having arranged and classified the order of Turkish language in terms of "showing meaning" and "providing expression" functions, this study consisted of three parts.

The introduction part is grounded on the foundations of the problem and the underlying reasons for conducting this study. The Turkish language was identified to transform the concept which is generally considered as a thinking tool into "word" while carrying it to the universe of language and marks the word through sounds. Turkish makes the sounds "words" and forms them for the word pattern/word. Turkish establishes its unique functioning in terms of language order on the basis of "sound and word". The "sound, word and phrase" is regarded as the unitization feature of Turkish in general. The reason for the presence of these basic units is to perform the function of "reconciliation", the reason for the existence of language. Thus, the basic language units of Turkish are assigned in terms of "meaning and expression" functions, which are the two basic elements of the reconciliation.

The second part of the study explains "showing meaning" function of language. Examples were provided about how the basic units of the language fulfilled the function of showing meaning. The semantic features of Turkish, which were discussed under three sub-headings as showing meaning with sound, with words and with phrases, were evaluated as a whole.

The third part covers the function of "providing expression" of Turkish. The transformations of the units that show meaning during the expression and the basic transformation feature in Turkish were emphasized. The study also reveals that the formal and semantic transformations of basic language units that transit between languages with language relations were carried out by adapting them to the functioning of Turkish. It was also pointed out that the situations, in which basic language units function directly and contextually, underwent transformations in terms of natural and functional knowledge of the language.

The study results revealed that the basic function (reconciliation) in Turkish is built on the concept, context and knowledge order, and therefore these features should be taken into account in the studies conducted on Turkish. Besides, this study drew attention to the fact that the specific functioning of languages can vary across the processes of language education and teaching, which is one of the main goals of grammar; moreover, grammar should be constructed in line with the functioning of Turkish.

This study attempted to draw the researchers' attention as to whether language provided communication or reconciliation. Turkish is a language that has the feature of saying everything it can get to the universe through words. This feature should be examined for other languages as well. Could the language analysis approach that Ferdinand de Saussure put forward with general linguistics be the same for every language? The results of this study suggested that the linguistic approach detects the common areas between languages, while they hide the peculiarities of existence of the languages. Language, by its very nature, must form natural units. The natural units of the language have been known for a long time as nouns, verbs and prepositions, but they also have uniting features according to the specific functioning of the language. One of the results of this study was the informational units of the language. 
Some of the suffixes and prepositions in Turkish are units with more than one function. Multifunctionality of language units may not be valid for all languages, but it is the general feature of language units in Turkish. The word "brave" refers to quality. It should be evaluated as an adjective, yet the same word can be used as a proper noun as well as a male person's name. "Ebucehil watermelon" is a type of watermelon and has nothing to do with the proper name "Abu Jahl". Time nouns are not only shown with words in Turkish but they can also be shown through the suffixes added to the words showing action (verb type word) apart from the time suffixes of verbs. The suffix "-InCA" in the sentence "I will ask when s/he comes" also marks the time. These features, which were detailed in the study, are classified according to the morphological features in Turkish grammar books. However, the arrangements and classifications determined according to the basic function of the language should be arranged by taking into account the functional features in order to be evaluated depending on the information order appropriate for the reason of the existence of the language. This implies that each language has its own information system and that Turkish language's own information system should be handled with this approach.

The study encourages new research with its theoretical aspect in terms of depicting the meaning and expression characteristics of Turkish. 